\title{
A Review on Miscanthus Biomass Production and Composition for Bioenergy Use: Genotypic and Environmental Variability and Implications for Breeding
}

\author{
Stéphanie Arnoult • Maryse Brancourt-Hulmel
}

Published online: 16 September 2014

(C) The Author(s) 2014. This article is published with open access at Springerlink.com

\begin{abstract}
The lignocellulosic C4 perennial crop miscanthus and, more particularly, one of its species, Miscanthus $\times$ giganteus, are especially interesting for bioenergy production because they combine high biomass production with a low environmental impact. However, few varieties are available, which is risky due to disease susceptibility. Gathering worldwide references, this review shows a high genotypic and environmental variability for traits of interest related to miscanthus biomass production and composition, which may be useful in breeding programs for enhancing the availability of suitable clones for bioenergy production. The $M$. × giganteus species and certain clones in the Miscanthus sinensis species seem particularly interesting due to high biomass production per hectare. Although the industrial requirements for biomass composition have not been fully defined for the different bioenergy conversion processes, the $M . \times$ giganteus and Miscanthus sacchariflorus species, which show high lignin contents, appear more suitable for thermochemical conversion processes. In contrast, the $M$. sinensis species and certain $M . \times$ giganteus clones with low lignin contents were interesting for biochemical conversion processes. The M. sacchariflorus species is also interesting as a progenitor for breeding programs, due to its low ash content, which is suitable for the different bioenergy conversion processes. Moreover,
\end{abstract}

\section{S. Arnoult $(\bowtie)$}

INRA, UMR1281 SADV, 2 Chaussée Brunehaut, Estrées-Mons, BP 50136, 80203 Péronne Cedex, France

e-mail: Stephanie.Arnoult@mons.inra.fr

M. Brancourt-Hulmel

INRA, UR1158 AgroImpact, Site d'Estrées-Mons, 2 Chaussée

Brunehaut, Estrées-Mons, BP 50136, 80203 Péronne Cedex, France

Present Address:

S. Arnoult

INRA, UE0972 GCIE Picardie, 2 Chaussée Brunehaut,

Estrées-Mons, BP 50136, 80203 Péronne Cedex, France mature miscanthus crops harvested in winter seem preferred by industry to enhance efficiency and reduce the expense of the processes. This investigation on miscanthus can be extrapolated to other monocotyledons and perennial crops, which may be proposed as feedstocks in addition to miscanthus.

Keywords Miscanthus · Phenotypic and genotypic variability $\cdot$ Biomass production $\cdot$ Biomass composition . Breeding $\cdot$ Bioenergy use

$\begin{array}{ll}\text { Abbreviations } \\ \text { DM } & \text { Dry matter } \\ \text { ha } & \text { Hectare } \\ \text { Gig } & \text { Miscanthus } \times \text { giganteus } \text { species } \\ \text { Sacc } & \text { Miscanthus sacchariflorus species } \\ \text { Sin } & \text { Miscanthus sinensis species } \\ \text { t } & \text { Ton }\end{array}$

\section{Introduction}

Currently, climate change and fossil fuel resource depletion are major global concerns. To limit climate change, reduce greenhouse gas emissions, and replace fossil fuel resources, renewable energy sources must be developed. Many reports have shown that biomass crops are significant contributors as bioenergy sources for heat, electricity, or biofuel production through thermochemical or biochemical processes [1-5].

Currently, a wide range of crops are biomass production candidates for bioenergy use: perennial $\mathrm{C} 4$ crops, such as miscanthus (Miscanthus), switchgrass (Panicum virgatum), or sugarcane (Saccharum officinarum L.); perennial C3 crops, such as reed canary grass (Phalaris arundinacea L.), giant reed (Arundo donax L.), short-rotation poplar coppices (Populus), or willow (Salix); annual C4 crops, such as fiber 
sorghum (Sorghum bicolor L.) or maize (Zea mays); or annual C3 crops, such as triticale (Triticum sativum) [6-15].

Among the few studies that have compared several such crops, the $\mathrm{C} 4$ perennial crops have been highlighted as advantageous for sustainable biomass feedstock [6].

For sustainable crops dedicated to producing bioenergy, the following must be combined: (i) high biomass production per hectare in various climates, (ii) suitable biomass composition for various bioenergy conversion processes, and (iii) positive environmental footprint (lowest water requirement, lowest $\mathrm{N}$, $\mathrm{P}$, and $\mathrm{K}$ fertilization, low greenhouse gas emissions, low invasiveness, etc.). For these requirements, $\mathrm{C} 4$ crops appear more promising as bioenergy crops than $\mathrm{C} 3$ crops because they are more productive and exhibit efficient water and nitrogen use [16] and efficient sunlight interception [17]. Among these C4 crops, C4 perennial crops such as miscanthus and switchgrass are particularly interesting because they yield a better environmental footprint than annual crops [6]. Moreover, perennial crops could be used to cover marginal lands for biomass production where annual crops are not suitable [18]. In comparison with switchgrass, miscanthus produces a higher biomass $[16,19]$ and also displays a larger solar energy conversion efficiency [20]. It is considered one of the most promising perennial bioenergy crops [15, 21-23]. More particularly, Miscanthus $\times$ giganteus, which is a triploid sterile hybrid descendent of a cross between Miscanthus sacchariflorus and Miscanthus sinensis [24], is particularly interesting because it combines high biomass production per hectare with a low environmental impact [6]. However, $M . \times$ giganteus also has certain disadvantages: (i) this species cannot produce high quantities of biomass under various climates because it is sensitive to heavy frost [25] and a lack of water [26], and further, (ii) $M \times$ giganteus, which has been the most commonly cultivated species until now, has only few clones [27, 28], which could be risky due to disease susceptibility [29].

Considering these disadvantages, developing miscanthus as suitable feedstock for bioenergy will enhance the miscanthus varieties available for cultivation. Therefore, miscanthus breeding programs must be developed to propose a range of miscanthus varieties that can produce high quantities of biomass per hectare under various climatic conditions. Other Miscanthus species could also be sought for breeding because the genus Miscanthus contains more than 20 species that originate from a broad geographical area [30]. Certain species, such as $M$. sinensis, show high genetic diversity compared with $M . \times$ giganteus $[27,28]$.

In addition to the above requirements for biomass production, using miscanthus as a feedstock for bioenergy requires that the biomass composition is adapted to various bioenergy conversion processes. This suitability remains a difficult challenge and constitutes a major bottleneck to proposing suitable lignocellulosic crops for bioenergy use.
First, the industrial requirements for lignocellulosic crop biomass composition have not been fully defined for the various bioenergy conversion processes. For instance, the most favorable balance between lignins, cellulose, and hemicelluloses in the cell wall for producing biofuels from biochemical conversion processes has not been defined [31].

In recent years, several global projects have been launched to precisely define these requirements and develop industrialscale tests for several bioenergy conversion processes. The results from these projects should precisely define the industrial requirements for lignocellulosic crop biomass composition in bioenergy production.

Second, biomass composition can influence bioenergy conversion process efficiency. For instance, high lignin content is positive for thermochemical processes [32,33], while it is negative for biochemical processes [34-36]. Regardless of the process, ash can be problematic because it deposits on the heat surfaces, which causes slagging and fouling [37, 38].

Third, the methods used to assess the biomass components and, more particularly, the cell wall components differ and are not reliable. Standardized methods have not been established for either miscanthus or other crops. This complicates the definition of the most suitable biomass composition for each bioenergy conversion process.

These observations demonstrate that biomass composition must be better understood and considered in miscanthus breeding programs to develop miscanthus as a suitable feedstock for bioenergy use.

Developing such breeding programs also requires consideration of interesting traits related to biomass production and composition as well as the factors of variation influencing such traits.

For the traits of interest, aboveground biomass production must be considered first. In addition, canopy height, stem number, or stem diameter, which are the main components that contribute to biomass production, must also be investigated [39-41]; cellulose, hemicellulose, lignin, and ash contents are the main traits considered in biomass composition.

For the factors of variation, studies on miscanthus have reported effects of species, clone, and ploidy level on biomass production and certain biomass production components [39-44] or biomass composition [33, 37, 43, 45-47]. Furthermore, these traits appear influenced by other factors, such as geographical area, climate conditions, or crop management practices, which can influence the conversion processes [33, 38, 44, 48-50].

Therefore, it is essential to consider the traits together with the factors of variation that can influence these traits in developing suitable miscanthus for bioenergy production.

Breeding program development requires knowing the genotypic variability related to the traits of interest [31]. As the 
genotypic variability related to biomass production and biomass composition has not been well studied for miscanthus, it is crucial to explore the variability in this genus for biomass production and composition.

Therefore, the present paper reviews worldwide references about the phenotypic variability in the Miscanthus genus for the following traits related to biomass production and biomass composition: aboveground biomass production, canopy height, stem number per plant, stem diameter, cellulose content, hemicellulose content, lignin content, and ash content. The phenotypic variability was deconstructed into environmental variability and genotypic variability to highlight the genotypic variability contribution that may be used in breeding programs. This paper gathered the available data for the three most studied Miscanthus species: M. × giganteus, M. sinensis, and $M$. sacchariflorus.

This paper is presented in four sections. The first section describes the data set used in the present review and collected from scientific literature. A second section investigates the phenotypic variability of the traits of interest related to miscanthus biomass production and biomass composition. In this section, environmental and genotypic variability are investigated with a focus on the factors of variation that are most studied in the literature. Given the miscanthus genotypic variability for biomass production and composition, in the third section, we discuss the miscanthus breeding implications for bioenergy use considering the industrial requirements for bioenergy conversion processes. Finally, we provide certain proposals in the fourth section.

\section{Database Description and Compilation}

A literature search was conducted using the Thomson Reuters Web of Knowledge electronic database for several traits of interest related to miscanthus biomass production and biomass composition.

The first observation is that the studies reporting data on these traits are relatively recent, with publication dates mainly ranging from 1997 to 2014. Certain miscanthus traits have not been thoroughly studied. Traits related to biomass production studied in literature mainly concern aboveground biomass production, canopy height, stem number, and stem diameter. Among these traits, fewer studies have considered canopy height, stem number, and stem diameter than aboveground biomass production. Fewer studies have considered traits related to miscanthus biomass composition than miscanthus biomass production. For the present review, we will focus on traits related to cell wall components (cellulose content, hemicellulose content, and lignin content) and ash content, which are interesting traits for industrial bioenergy production.

A second observation is that the studies differed.

First, the data from each publication were not comparable for a given trait; certain publications indicate individual values for each factor of variation (year, harvest date, nitrogen, location, genotype, etc.), and others reported only a mean value for a given trait. Therefore, to investigate the traits of interest related to miscanthus biomass production and biomass composition in this review, we selected publications that allowed us to collect individual data for each trait. Therefore, each individual data has the same weight and was comparable between publications.

Secondly, different factors of variation for such traits in the literature were discussed. In this review, we focus on the factors related either to crop age, climate conditions, geographical area, crop management practices (harvest date, nitrogen fertilization, irrigation, or plant density), species, clones, or ploidy level, which were the most commonly studied factors in the literature. For the crop age, most studies reported data for the first 3 years of cultivation. Therefore, we focus on these first 3 years to investigate the influence of crop age on these traits. In addition, only three Miscanthus species have been investigated in the literature for traits related to biomass production and composition: $M . \times$ giganteus, M. sinensis, and M. sacchariflorus. Moreover, the clone number and genetic background in the literature differed between the three species. Therefore, to compare the publications based on the Miscanthus species, we categorized the genotypes into three groups: (i) interspecific $M$. $\times$ giganteus-type hybrids that correspond to $M$. $\times$ giganteus clones or M. sacchariflorus $\times$ M. sinensis clones, (ii) M. sinensis species that correspond to $M$. sinensis clones or intra-specific hybrids between $M$. sinensis clones, and (iii) M. sacchariflorus species that correspond to $M$. sacchariflorus clones or intra-specific hybrids between $M$. sacchariflorus clones.

Third, the method used to determine the values for traits related to biomass composition differed between studies. The cellulose, hemicellulose, and lignin contents were determined using several chemical analysis methods, such as the Van Soest method, the KS M 7044 method to determine cellulose content, or the Klason method to determine lignin content [51, 52]. Based on the method used, the cellulose, hemicellulose, or lignin contents differed and may be underestimated or overestimated (Chabbert, personal communication). Therefore, to ensure reliable comparisons for such contents between publications, we focused only on the publications that used the Van Soest method as the method of reference [53] because it was most commonly used [33, 45, 54-56].

Herein, Tables 1 and 2 gather the publications which reported data on the miscanthus phenotypic variability for the traits of interest. For each study, we provide information 


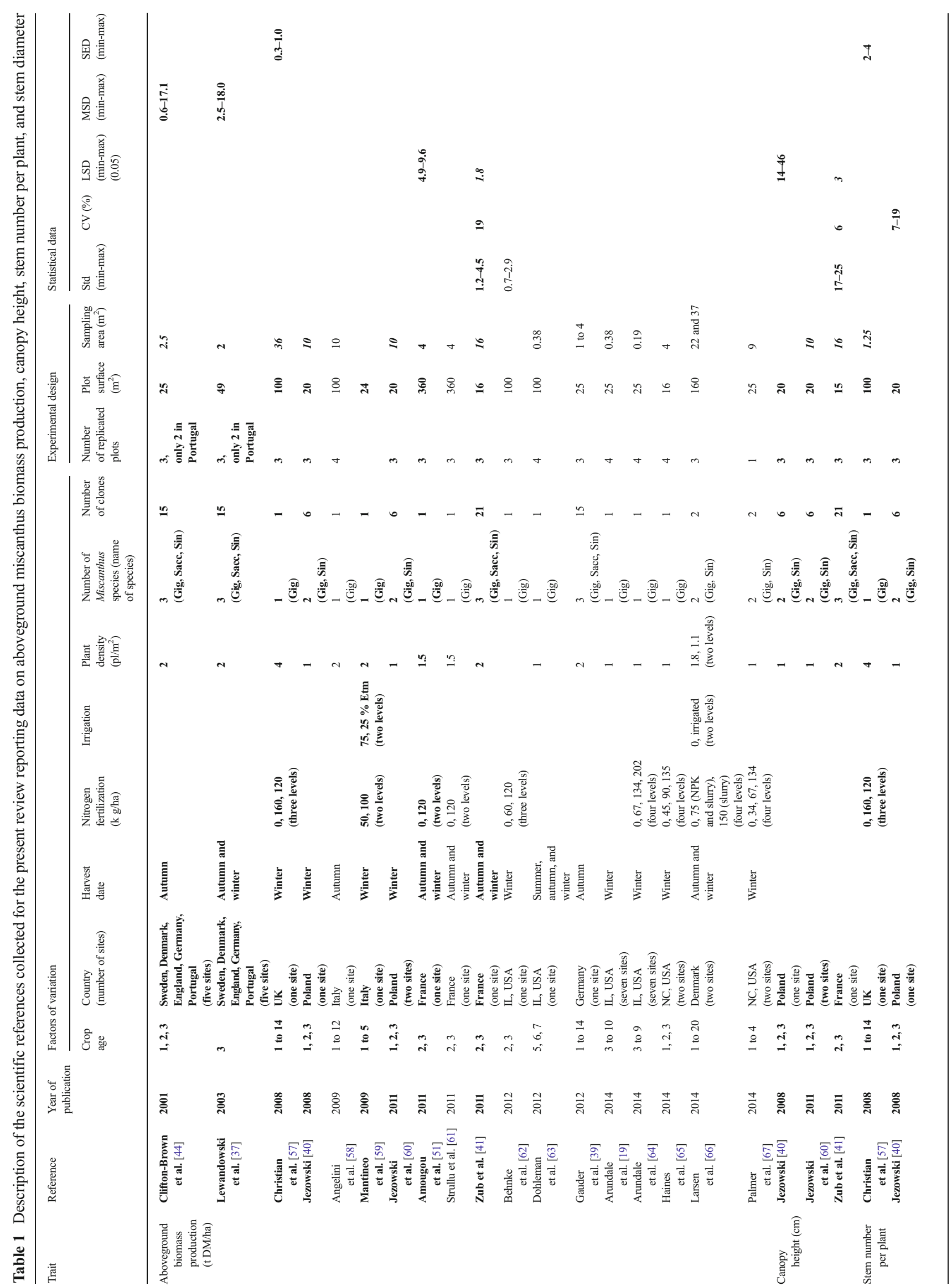




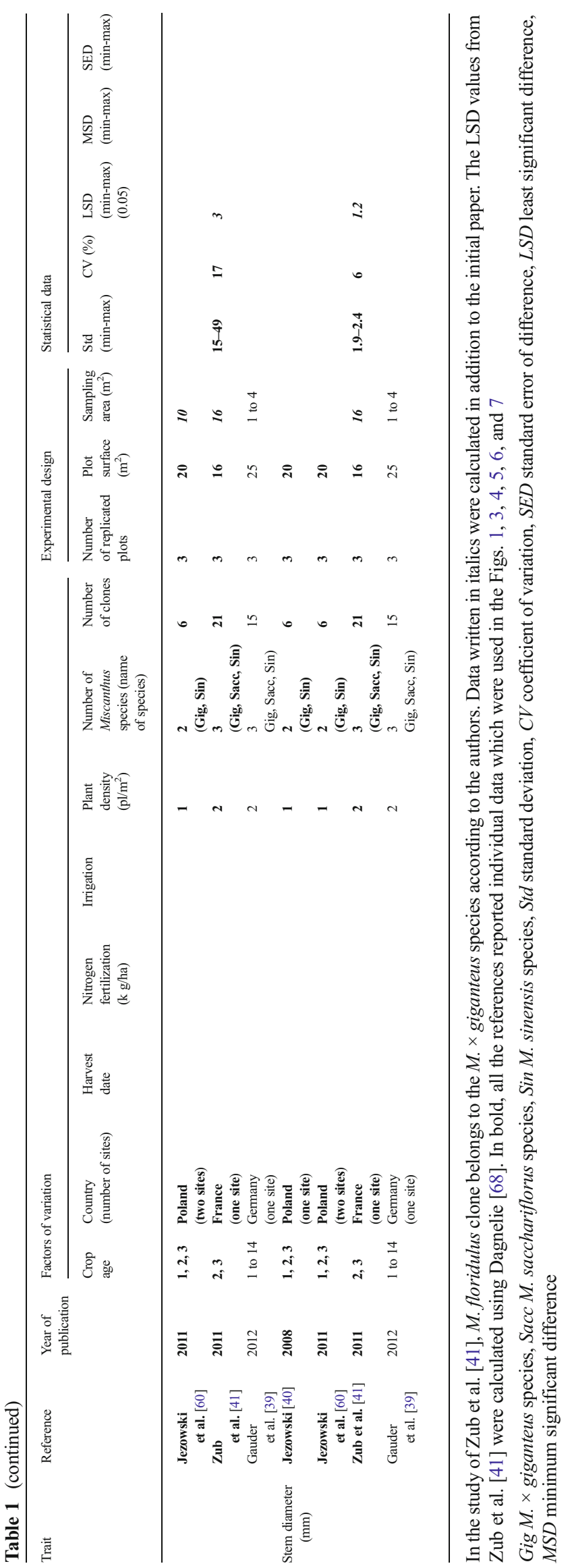




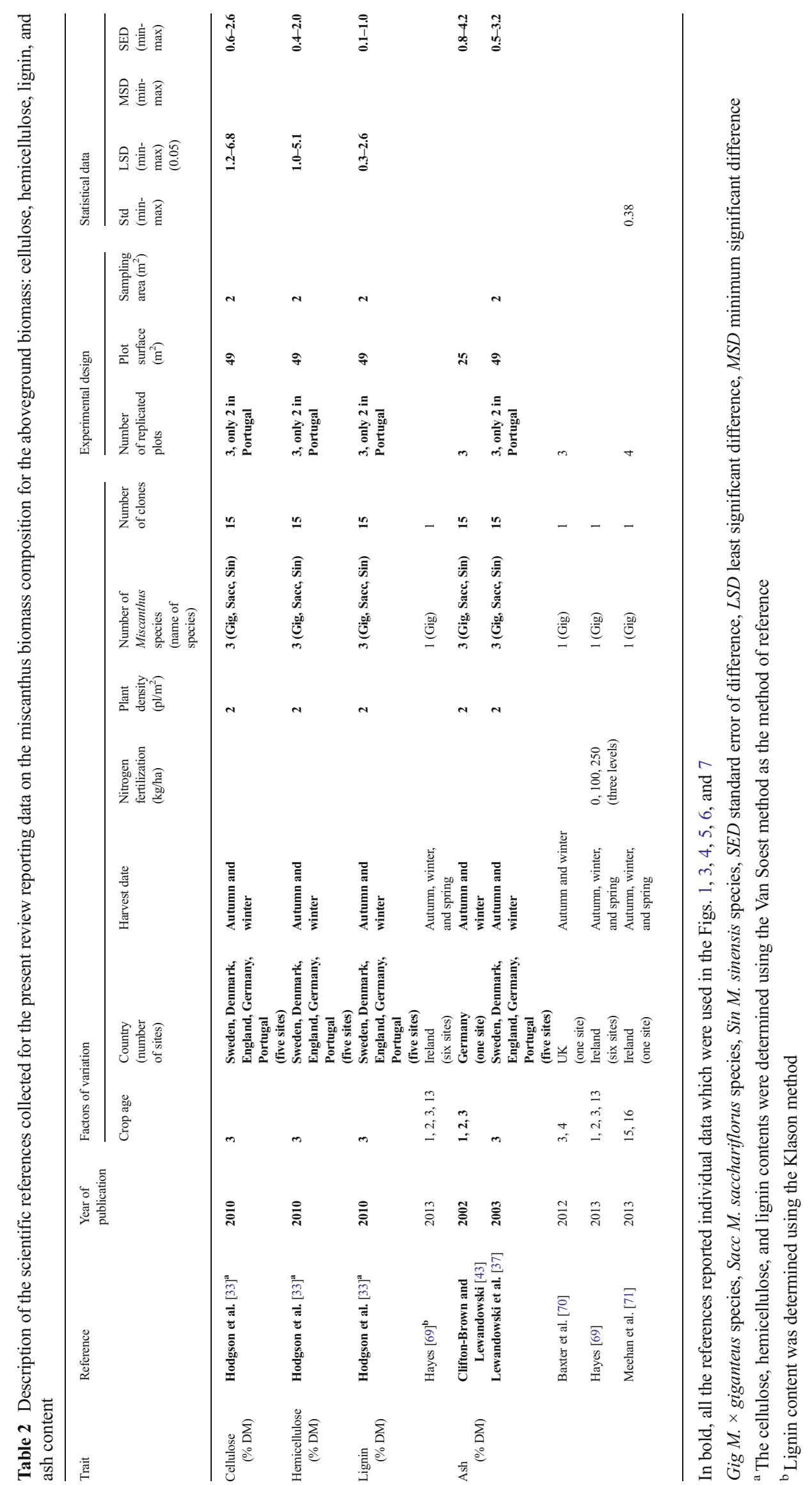



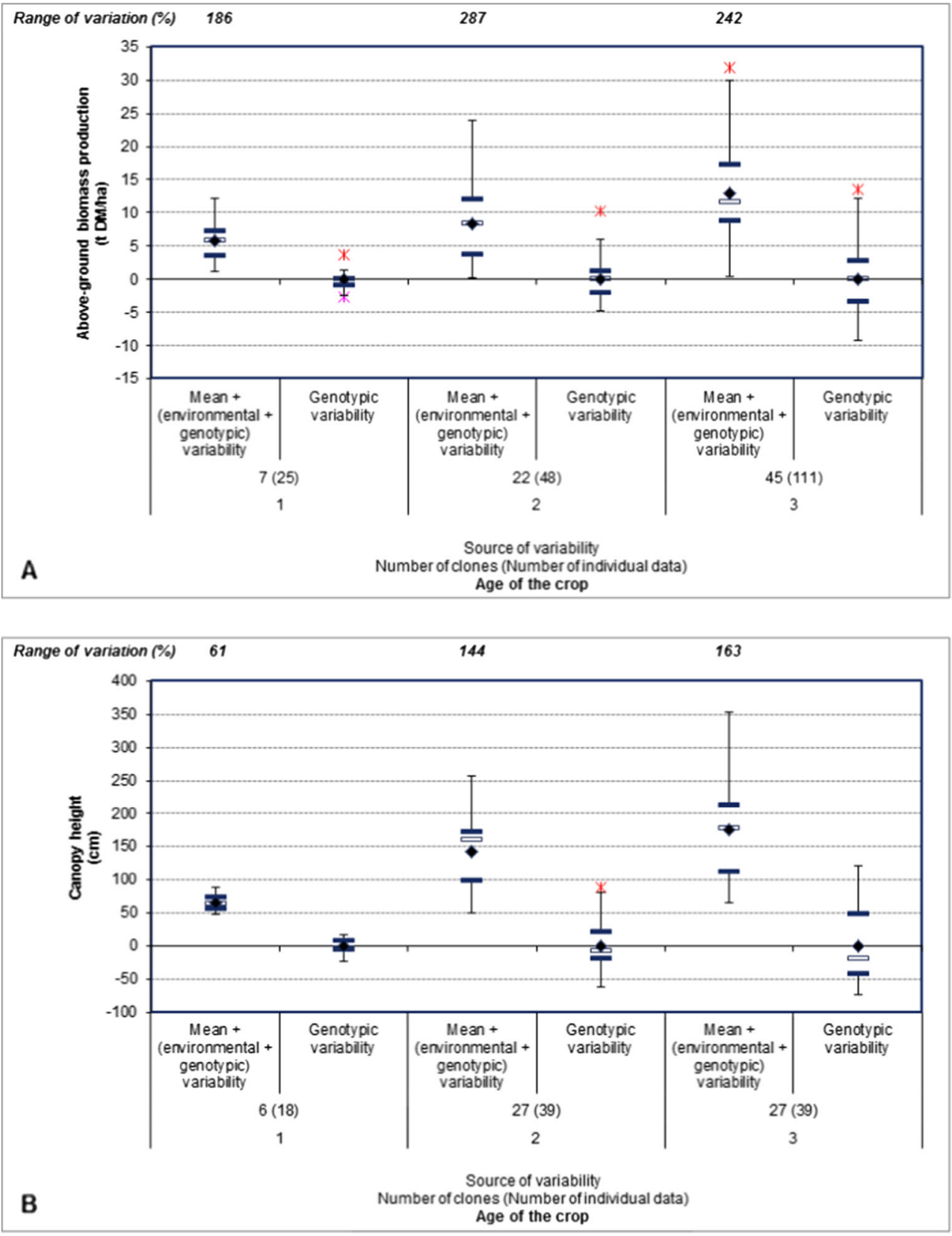

Fig. 1 Phenotypic variability and genotype contribution to the phenotypic variability in miscanthus for aboveground biomass production (a), canopy height (b), stem number per plant (c), and stem diameter (d) based on the crop age, from the first to third year of cultivation. Phenotypic variability corresponds to the mean + (environmental + genotypic variability); the genotype contribution to the phenotypic variability corresponds to genotypic variability. The aboveground biomass production was assessed for the winter harvest; the canopy height, stem number per plant, and stem diameter were obtained at the end of the growing season. The mean value (indicated by the black diamond) was calculated from the individual data collected in the literature for each year of cultivation. The ends of the vertical lines correspond to the minimum and maximum

related to the factors of variation, experimental design construction, and statistical indices.

To investigate each trait, we selected in Tables 1 and 2 the studies for which individual data were available (in bold in the values; the black horizontal lines correspond to the upper and lower quartiles; and the white horizontal lines correspond to the median for each year of cultivation. The stars on both sides of the black horizontal lines correspond to the outlier values. The range of variation corresponds to the difference between the maximum and minimum values and is expressed as a percentage of the mean. References used - a Christian et al. [57], Clifton-Brown et al. [44], Lewandowski et al. [37], Jezowski [40], Jezowski et al. [60], Mantineo et al. [59], Amougou et al. [51], Zub et al. [41]; b Jezowski [40], Jezowski et al. [60], Zub et al. [41]; c Jezowski [40], Christian et al. [57], Jezowski et al. [60], Zub et al. [41]; d Jezowski [40], Jezowski et al. [60], Zub et al. [41]

tables). We represented these individual data using box-plots (Figs. 1, 3, 4, 5, 6, and 7). Two types of box-plots were constructed for each illustration: a first type of box-plot shows the phenotypic variability that combines both environmental 

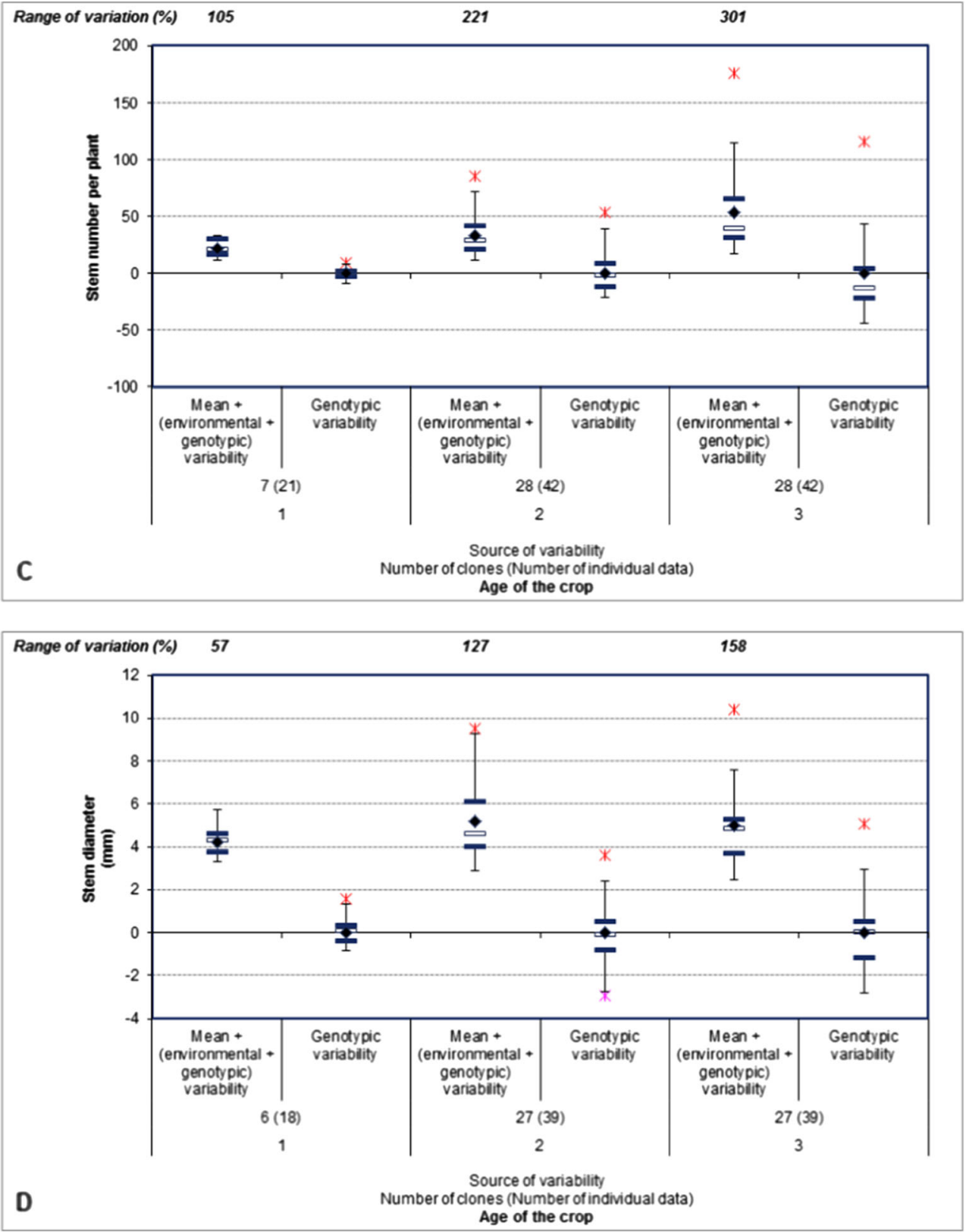

Fig. 1 (continued)

and genotypic variability, and a second type shows the part of the phenotypic variability due only to the genotype. This genotype effect $\left(\alpha_{i}\right)$ was calculated in each collected environment according to the following additive model including the studied factors:

$E\left(Y_{i}\right)=\mu+\alpha_{i}+$ other factor effects

In addition, the range of variation was calculated for each trait.

Finally, the remaining references of the Tables 1 and 2 are cited in the text to support the discussion.

\section{The Phenotypic Variability for the Traits of Interest}

The Phenotypic Variability for Aboveground Biomass

Production and Biomass Components

The Influence of Crop Age

Miscanthus is a perennial crop that can be cultivated for up to 25 years [72], during which miscanthus biomass is produced in two phases: a yield-building phase, where the biomass gradually increases, and an adult phase often described as a plateau phase, where the biomass production is maintained $[29,42,73]$. 
Fig. $2 M . \times$ giganteus aboveground biomass production during the winter harvest for several successive years from Christian et al. [57], Gauder et al. [39], and Cadoux et al. [6]

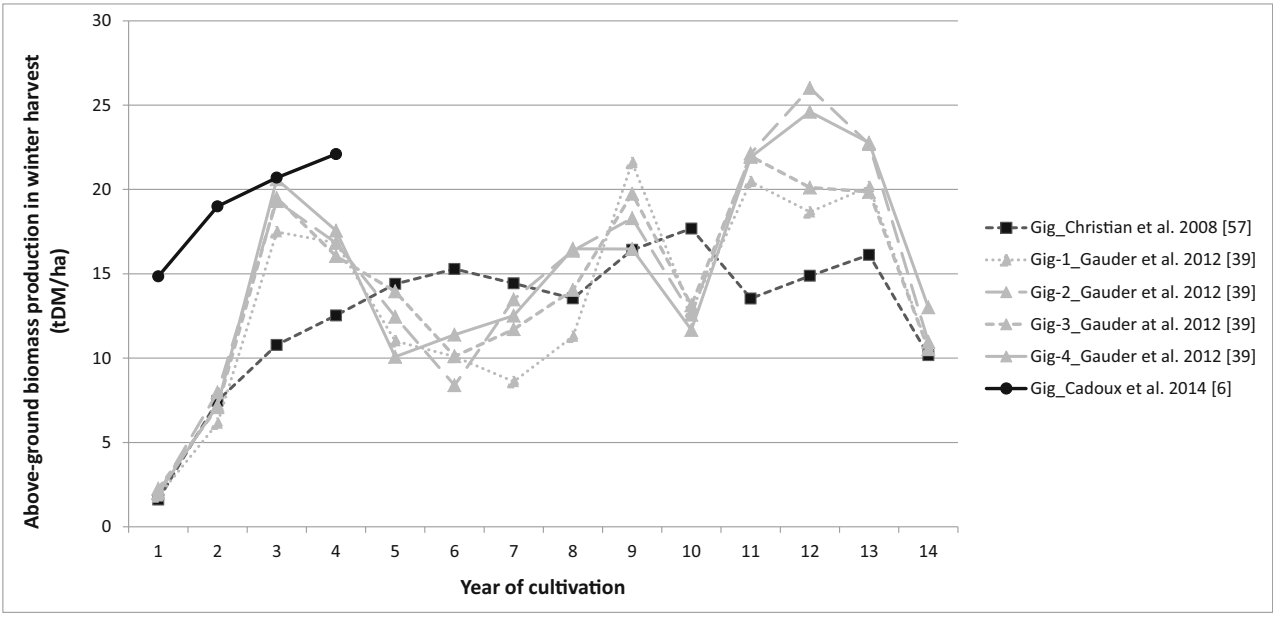

Most studies in the literature have reported data on miscanthus aboveground biomass production and components for the first 3 years of cultivation, which correspond to the yield-building phase (Table 1). Data on these traits for subsequent years were less frequent in the literature and only concern the M. $\times$ giganteus species, which is the most commonly studied species $[6,38,57,59]$.

Therefore, in the following, we describe the influence of crop age on the aboveground biomass and its components based on the two biomass production phases. We better detail the first three cultivation years because more information is available in literature.
- The first years: the yield-building phase

The first year of cultivation corresponds to the year that the crop is established [29]. The biomass production is generally low during the first year with a $5.9 \mathrm{t}$ dry matter/ha (DM/ha) average from experiments using irrigated or rainfall conditions (Fig. 1a).

During the 2 years that follow, the miscanthus biomass gradually increases: biomass production reaches 8.3 and $13.0 \mathrm{t} \mathrm{DM} / \mathrm{ha}$ on average during the second and third years, respectively, under irrigated or rainfall conditions (Fig. 1a).

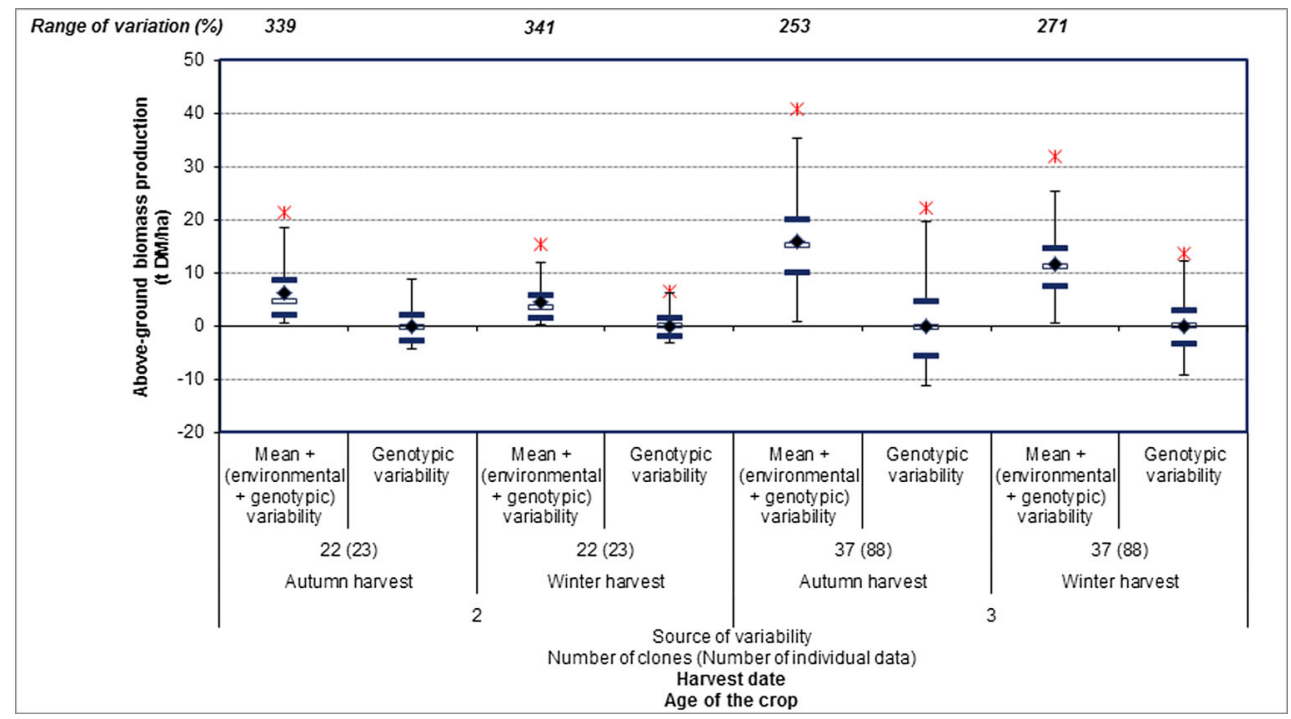

Fig. 3 The phenotypic variability and genotype contribution to the phenotypic variability for aboveground miscanthus biomass production based on the harvest date (autumn and winter harvests) during the second and third years of cultivation. The phenotypic variability corresponds to the mean + (environmental + genotypic variability); the genotype contribution to the phenotypic variability corresponds to the genotypic variability. The mean value (indicated by the black diamond) was calculated from the individual data collected in the literature for each year of cultivation and harvest date. The ends of the vertical lines correspond to the minimum and maximum values; the black horizontal lines correspond to the upper and lower quartiles; and the white horizontal lines correspond to the median for each year of cultivation and harvest date. The stars on both sides of the black horizontal lines correspond to the outlier values. The range of variation corresponds to the difference between the maximum and minimum values and is expressed as a percentage of the mean. References used-Lewandowski et al. [37], Zub et al. [41], Amougou et al. [51] 

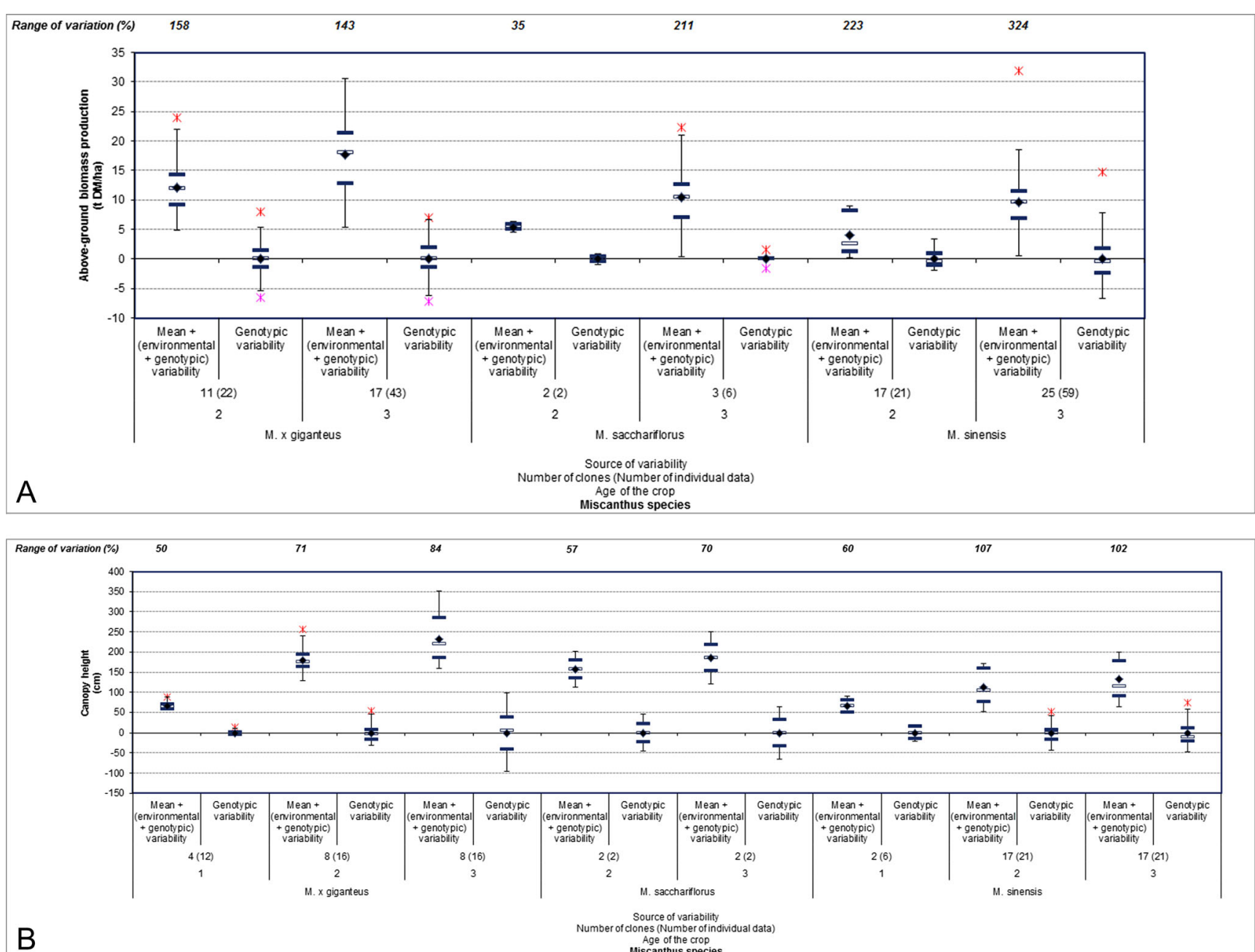

Fig. 4 The phenotypic variability and genotype contribution to the phenotypic variability for aboveground miscanthus biomass production (a), canopy height (b), stem number per plant (c), and stem diameter (d) among and within the three Miscanthus species M. $\times$ giganteus, M. sacchariflorus, and M. sinensis for the first 3 years of cultivation. The phenotypic variability corresponds to the mean + (environmental + genotypic variability); the genotype contribution to phenotypic variability corresponds to genotypic variability. The aboveground biomass production was assessed for the winter harvest; the canopy height, stem number per plant, and stem diameter were obtained at the end of the growing season. The mean value (indicated by the black diamond) was calculated from the individual data collected in the literature for each year of cultivation. The ends of the vertical lines correspond to the minimum and maximum values; the black horizontal lines correspond to the upper and lower quartiles; and the white horizontal lines correspond to the

Biomass components, such as canopy height and stem number per plant, also clearly increase from the first to third year; on average, the canopy height increases from 66 to $176 \mathrm{~cm}$, and the stem number per plant increases from 21 to 53 (Fig. 1b, c). However, with mean values between 4.2 and $5.2 \mathrm{~mm}$, the stem diameter was more consistent than the biomass production, canopy height, and stem number during the first 3 years (Fig. 1).

These observations confirmed that for miscanthus, the first 3 years correspond to a yield-building phase, where median for each year of cultivation. The stars on both sides of the black horizontal lines correspond to the outlier values. The range of variation corresponds to the difference between the maximum and minimum values and was been expressed as a percentage of the mean. For each trait, genotypic variability in the $M$. sacchariflorus species during the second year was the same as the phenotypic variability; the two M. sacchariflorus genotypes were observed in a single environment. No data were available for canopy height (b), stem number per plant (c), and stem diameter (d) on the first year of cultivation for the M. sacchariflorus species in the literature. References used-a Christian et al. [57], Lewandowski et al. [37], Jezowski [40], Jezowski et al. [60], Mantineo et al. [59], Amougou et al. [51], Zub et al. [41]; b Jezowski [40], Jezowski et al. [60], Zub et al. [41]; c Christian et al. [57], Jezowski [40], Jezowski et al. [60], Zub et al. [41]; d Jezowski [40], Jezowski et al. [60], Zub et al. [41]

the biomass production and its components, such as canopy height and stem number per plant, gradually increase.

The range of variation was large within each of the first 3 years of cultivation for each trait. This range of variation was generally smaller during the first year of cultivation compared with the second and third years (Fig. 1). In addition, the data scattering for biomass production, stem number, canopy height, and stem diameter, to a lesser extent, increased each year during the first 3 years; minimum values were consistent among the years, but the 

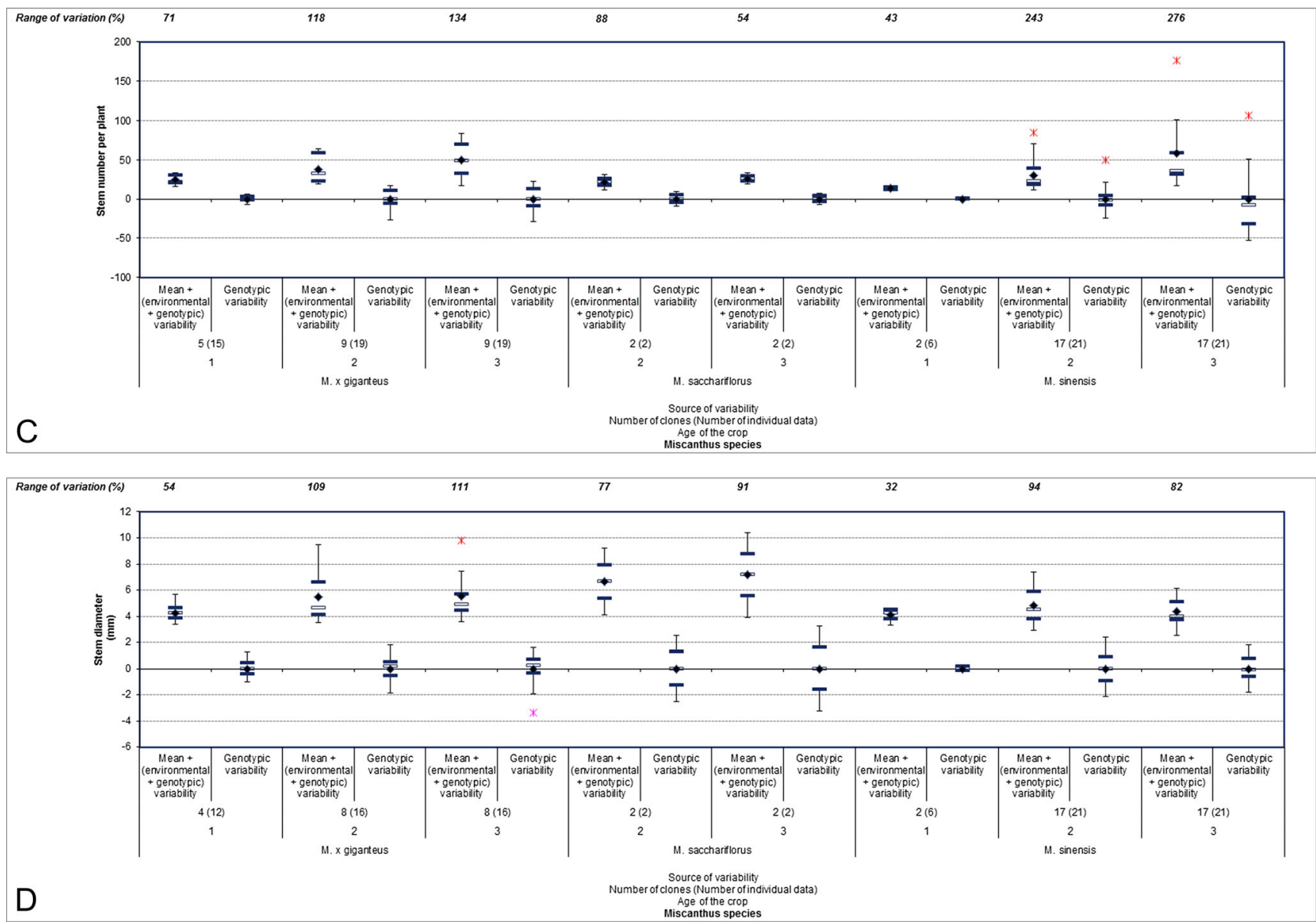

Fig. 4 (continued)

maximum values increased each year (Fig. 1). Similarly, genotypic variability was more visible in the second and third years than the first year for each trait studied; the higher variability in second and third years was certainly due to the most productive genotypes, which began to display their potential during the second year.

Finally, among the traits studied, stem number and aboveground biomass production appeared to be the most variable traits (301 and $242 \%$, respectively, in the third year) compared with canopy height and stem diameter, which seemed less variable (163 and $158 \%$, respectively, in the third year) (Fig. 1). This large observed range of variation for the traits related to biomass production was particularly interesting in breeding programs to select the best genotypes and achieve maximum biomass production.

- The subsequent years: the adult phase and decline

Several studies have reported data on miscanthus biomass production, canopy height, stem number, or stem diameter in long-term experiments. They mainly concerned long-term biomass production which was reported for the M. $\times$ giganteus species in Europe (France [6], UK
[57], Germany [39], Italy [58], Denmark [66]) and in the USA (Illinois [19, 63]). The winter harvest date corresponded to the harvest date commonly used by farmers. From the available individual data, we assume that the $M . \times$ giganteus biomass production crop reached a first peak at variable time: at 3 years in the study of Gauder et al. [39], at 6 years in the study of Christian et al. [57], and this first peak was not reached after 4 years of cultivation in the study of Cadoux et al. [6] (Fig. 2). CliftonBrown et al. [42] in the UK and Miguez et al. [74] in the USA showed that biomass production plateaued after 2 to 5 years for $M$. $\times$ giganteus depending on the environmental conditions and crop management practices. Larsen et al. [66] reported in Denmark an increase of the $M$. × giganteus biomass production during the first years, optimum yields after 7 and 8 years, and a decrease to a lower level which remained relatively constant from year 11 to 20. In addition, Gauder et al. [39] found even more variable yields from the 3 rd to the 14th years of cultivation.

In summary, based on the long-term experimental data published, it is difficult to estimate the time of the first peak of production and the length of time that miscanthus maintains biomass production. It seems also that the yields 


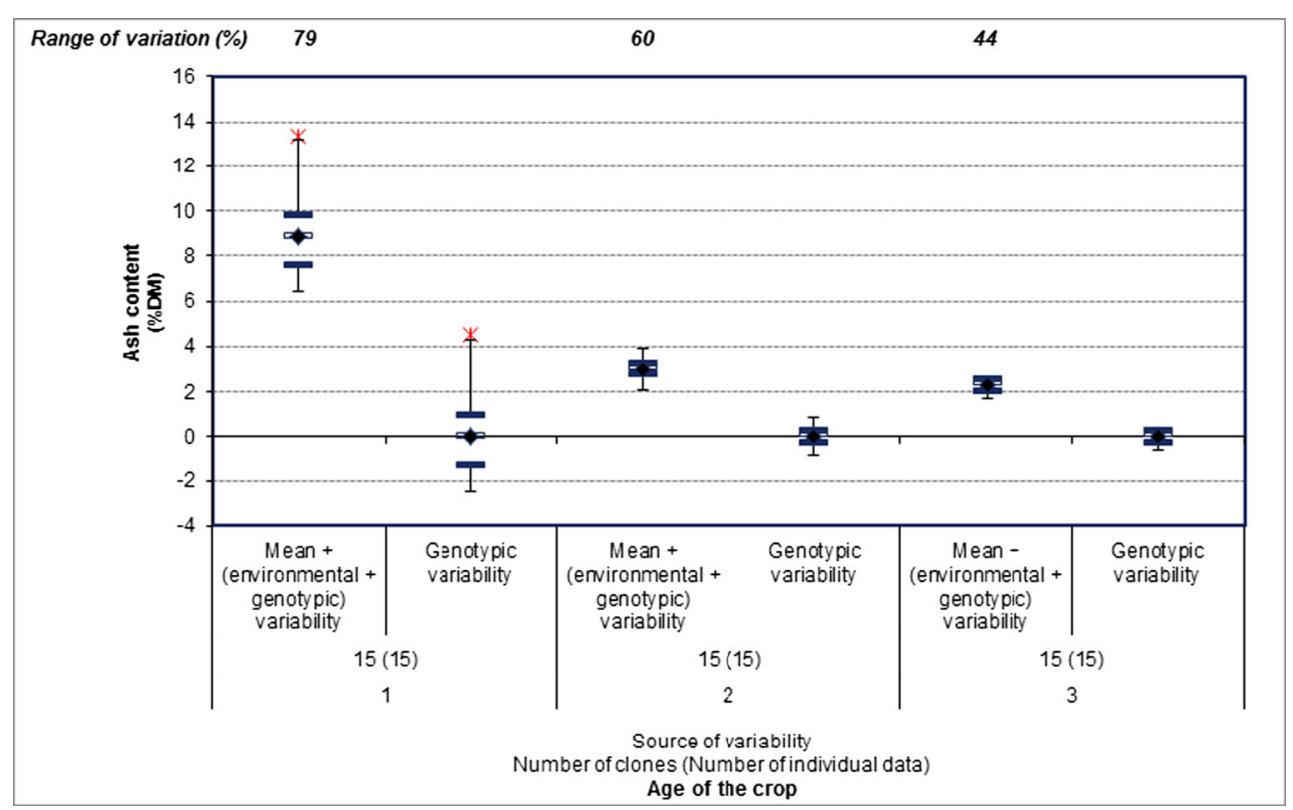

Fig. 5 The phenotypic variability and genotype contribution to the phenotypic variability for aboveground miscanthus ash content based on the crop age from the first to third year during the winter harvest based on Clifton-Brown and Lewandowski [43]. The phenotypic variability corresponds to the mean + (environmental + genotypic variability); the genotype contribution to the phenotypic variability corresponds to genotypic variability. The mean value (indicated by the black diamond) was calculated from the individual data collected in the literature for each year of cultivation. The ends of the vertical lines correspond to the minimum

during the plateau phase are variable. Lastly, the time that biomass production begins to decline is also variable. This variability during the plateau phase and the variability of the time of the decline depend on possible causes such as the soil and climate conditions as well as crop management practices [74]. In addition, the biomass production decline depends itself on soil compaction and pest and disease pressure [19].

\section{The Influence of Climate Conditions}

Climate conditions, such as temperature, affect miscanthus biomass production more during the first year of crop establishment. For instance, a severe frost that occurs immediately after establishment can cause plant death in $M . \times$ giganteus and irreversibly damage biomass production [25]. In addition, low temperatures during the first winter after planting can damage miscanthus biomass production. For instance, $M$. × giganteus and $M$. sacchariflorus clones died the first winter after planting in Sweden and Denmark, whereas M. sinensis clones survived [44]. The authors explained the plant death by the winter soil temperatures, which fell below $-4.5{ }^{\circ} \mathrm{C}$ during the first year after planting in these countries. and maximum values; the black horizontal lines correspond to the upper and lower quartiles; and the white horizontal lines correspond to the median for each year of cultivation. The stars on both sides of the black horizontal lines correspond to the outlier values. The range of variation corresponds to the difference between the maximum and minimum values and is as a percentage of the mean. For each of the 3 years, the genotypic variability equaled the phenotypic variability; the 15 genotypes were observed in a single environment

During subsequent years of cultivation, Jezowski et al. [60] concluded that climate conditions significantly affected miscanthus biomass production based on the experiment location by comparing two sites in Poland during the first 3 years of cultivation. Clifton-Brown et al. [44] also concluded that biomass production varied based on the trial location; they showed that biomass production was generally higher in Central and Southern Europe than Northern Europe over the first 3 years of cultivation. Moreover, Clifton-Brown et al. [44] concluded that the clone and country significantly interacted; clones that produced the highest yields in Sweden and Denmark were among clones that produced the lowest yields in Portugal and Germany. Despite this interaction, the authors showed that certain $M$. sinensis hybrids can be found for a wide range of climate conditions in Europe. Gauder et al. [39] and Heaton et al. [75] also reported that climate parameters, such as rainfall and temperature, were important in miscanthus biomass accumulation. More particularly, in Germany, Gauder et al. [39] reported a strong correlation between the rainfall level during plant growth and miscanthus biomass production for a winter harvest.

Therefore, climate conditions can irreversibly damage biomass production during the first year of cultivation, which corresponds to the establishment year. This observation implies that climate conditions should be considered during the 

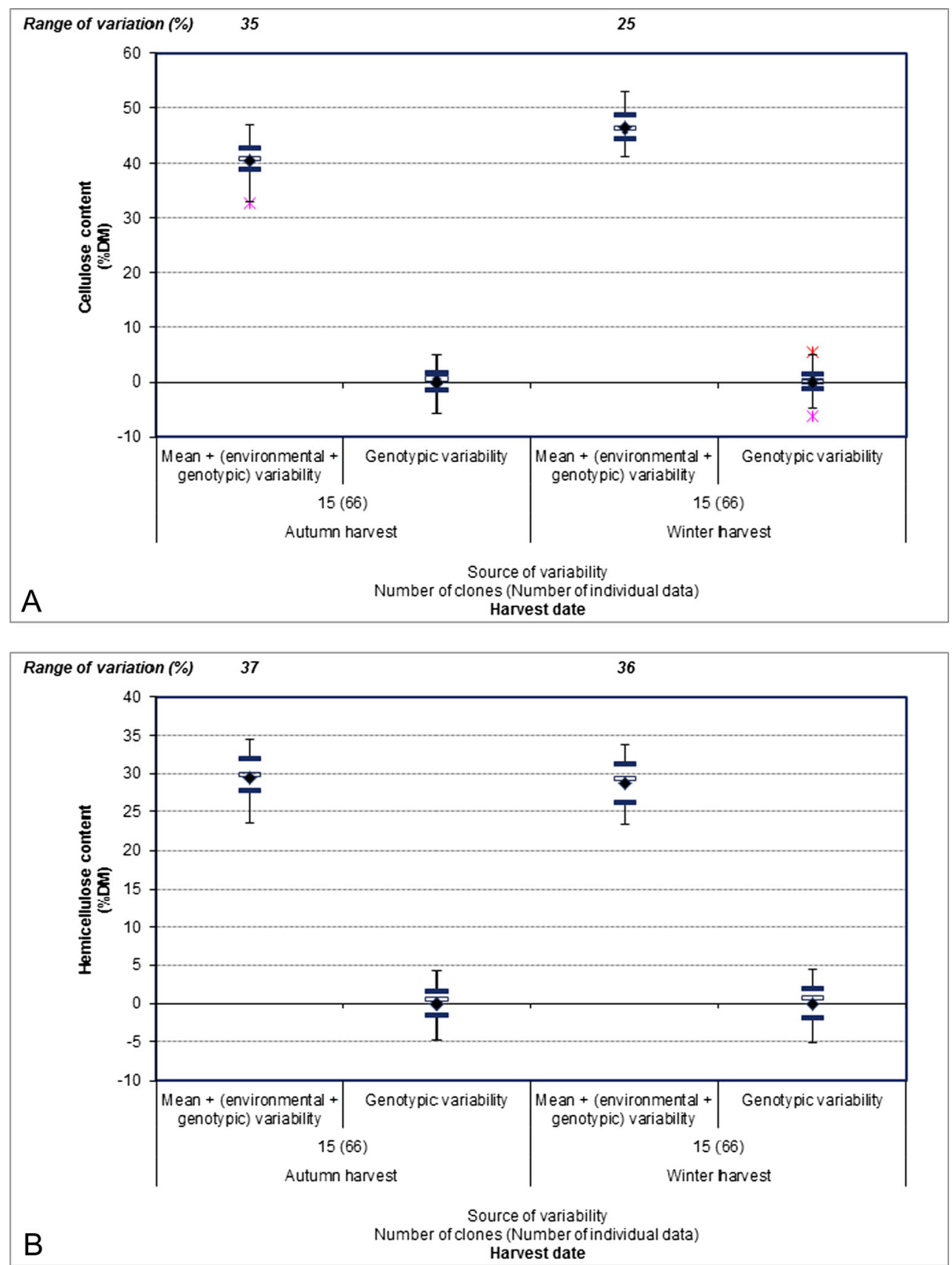

Fig. 6 The phenotypic variability and genotype contribution to the phenotypic variability for aboveground miscanthus cellulose content (a), hemicellulose content (b), lignin content (c), and ash content (d) between the autumn and winter harvests during the third year of cultivation. The phenotypic variability corresponds to the mean + (environmental + genotypic variability); the genotype contribution to phenotypic variability corresponds to the genotypic variability. Cellulose, hemicellulose, and lignin contents were determined using the Van Soest method as the method of reference. The mean value (indicated by the black diamond) was calculated from the individual data collected in the

first year, as it was the most critical phase for biomass production [76]. Variations in climate conditions, such as rainfall and temperature, can also influence biomass production during the subsequent years of cultivation. Therefore, to maximize literature for each year of cultivation. The ends of the vertical lines correspond to the minimum and maximum values; the black horizontal lines correspond to the upper and lower quartiles; and the white horizontal lines correspond to the median for each year of cultivation. The stars on both sides of the black horizontal lines correspond to the outlier values. The range of variation corresponds to the difference between the maximum and minimum values and is expressed as a percentage of the mean. References used-a-c Hodgson et al. [33]; d Clifton-Brown and Lewandowski [43], Lewandowski et al. [37]

biomass production, Miscanthus genotypes have to be selected based on their climate condition requirements because an interaction between location and genotype was observed for biomass production [44]. 

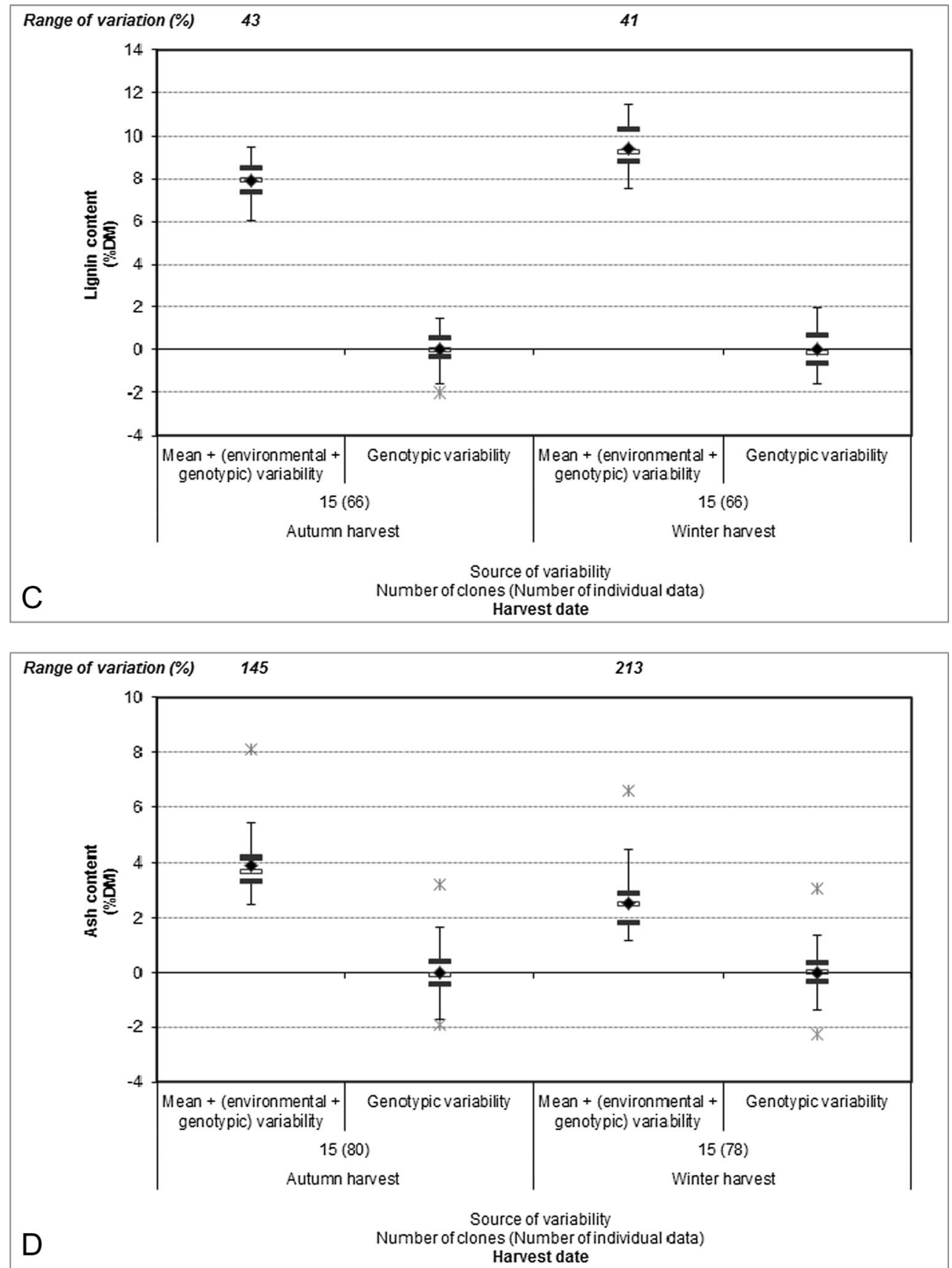

Fig. 6 (continued)

\section{The Influence of Crop Management Practices}

- The influence of harvest date

On average, $1.8 \mathrm{t} \mathrm{DM} / \mathrm{ha}(29 \%)$ and of $4.2 \mathrm{t} \mathrm{DM} / \mathrm{ha}(26 \%)$ decreases were observed between the autumn and winter harvests for the second and third years, respectively (Fig. 3). For each growing season, maximum biomass productions were obtained during autumn at flowering [26] then declined during winter mainly due to leaf loss, senescence, and assimilate translocation $[41,43,77,78]$.
With variations ranging from 253 to $341 \%$, biomass production was highly variable during each year and each harvest date (Fig. 3). Interestingly, the data appeared more scattered during the autumn harvests than winter harvests (Fig. 3).

Finally, the genotype contribution to the phenotypic variability was high for aboveground biomass production and more visible during the third than second year for both harvest dates (Fig. 3).

In addition, Strullu et al. [61] showed on M. $\times$ giganteus an interaction of the harvest date with the nitrogen 

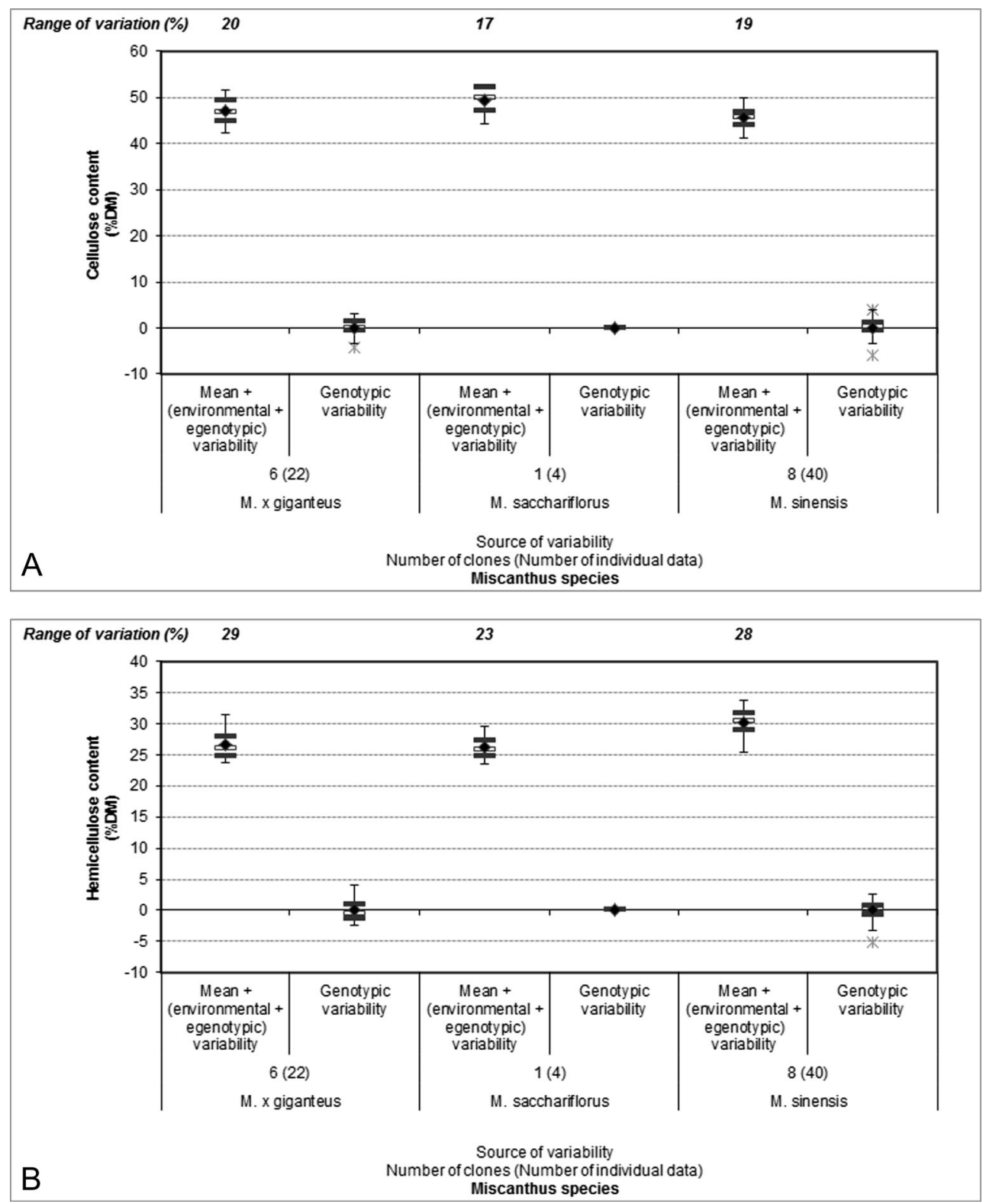

Fig. 7 The phenotypic variability and genotype contribution to the phenotypic variability in miscanthus among and within the three Miscanthus species $M . \times$ giganteus, $M$. sacchariflorus, and M. sinensis for cellulose content (a), hemicellulose content (b), lignin content (c), and ash content (d) in the aboveground biomass during winter harvest in the third year of cultivation. The phenotypic variability corresponds to mean + (environmental + genotypic variability); the genotype contribution to the phenotypic variability corresponds to genotypic variability. The cellulose, hemicellulose, and lignin contents were determined using the Van Soest method as the method of reference. The mean value (indicated by the black diamond) was calculated from the individual data collected in

fertilization: in winter harvest, there was no effect of the nitrogen treatment whereas in autumn harvest, the biomass production increased with the nitrogen fertilization.

- The influences of nitrogen fertilization and irrigation Most studies investigated the effects of nitrogen input the literature for each year of cultivation. The ends of the vertical lines correspond to the minimum and maximum values; the black horizontal lines correspond to the upper and lower quartiles; and the white horizontal lines correspond to the median for each year of cultivation. The stars on both sides of the black horizontal lines correspond to the outlier values. The range of variation corresponds to the difference between the maximum and minimum values and is expressed as a percentage of the mean. For each trait, the genotypic variability of the $M$. sacchariflorus species equaled zero; only one $M$. sacchariflorus genotype was observed. References used-a-c Hodgson et al. [33]; d Clifton-Brown and Lewandowski [43], Lewandowski et al. [37]

levels and irrigation on $M . \times$ giganteus biomass production until now, excepting the study of Palmer et al. [67].

In a review, Cadoux et al. [79] concluded that the effect of nitrogen fertilization on aboveground $M . \times$ giganteus biomass production varied. Certain studies reported no effect from nitrogen fertilization on aboveground $M$. × giganteus biomass production $[51,57,59,62,80]$. Other 

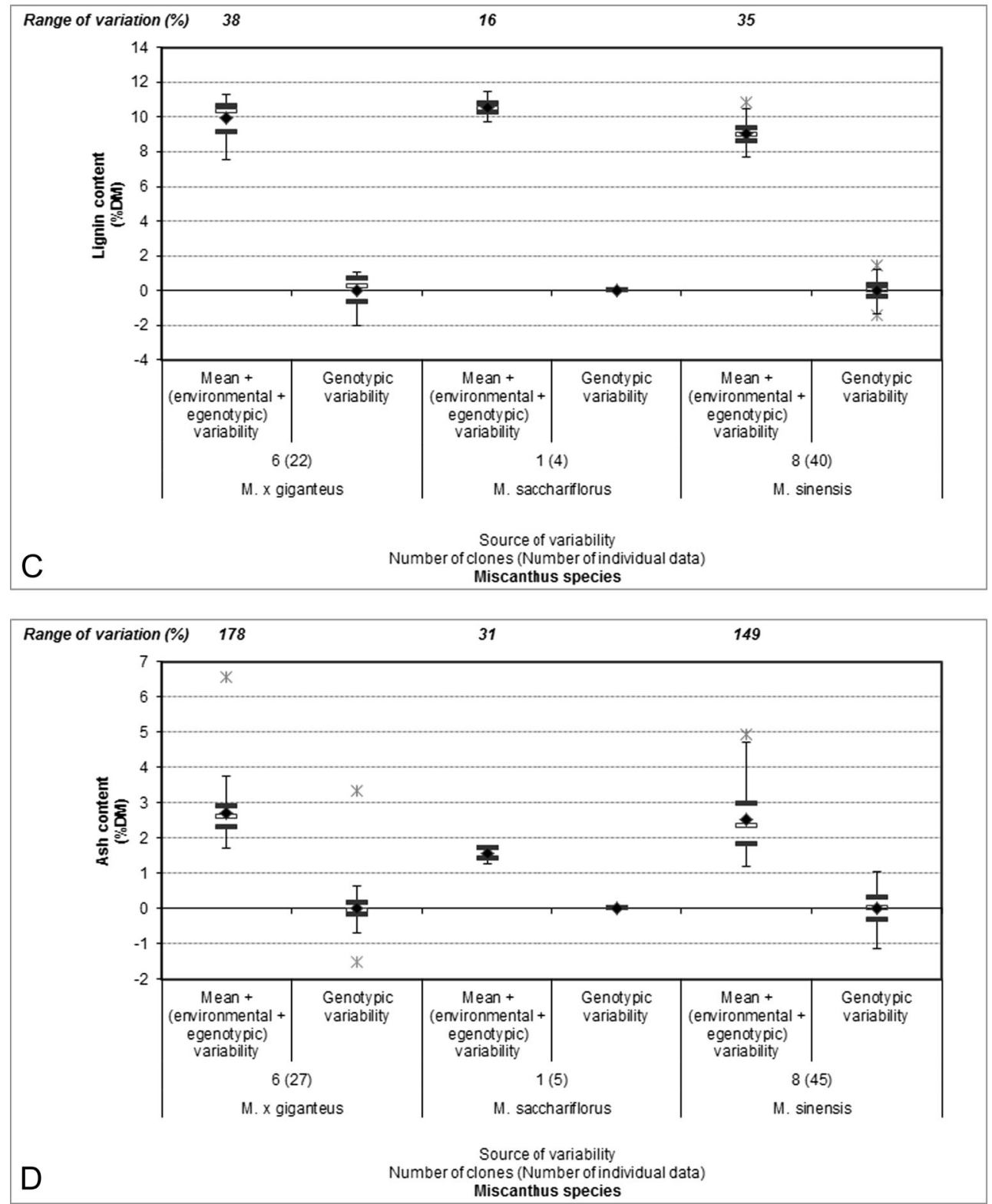

Fig. 7 (continued)

studies have reported a positive effect on the aboveground biomass for nitrogen input ranging from 0 to $200 \mathrm{~kg} \mathrm{~N} / \mathrm{ha}$ $[6,26,64,81,82]$. More recently, variable effects for nitrogen fertilization were even observed on the biomass production between years [65].

As reported by Cadoux et al. [79], the effect from nitrogen fertilization on aboveground $M . \times$ giganteus biomass production was generally limited but the effect was amplified with irrigation. For instance, during the third year of cultivation, Mantineo et al. [59] observed maximum $M$. $\times$ giganteus biomass production with the highest nitrogen fertilization level $(100 \mathrm{~kg} \mathrm{~N} / \mathrm{ha})$ and under the best soil water content conditions ( $75 \%$ water restoration in the soil with maximum evapotranspiration). Moreover, Ercoli et al.
[82] concluded that the effect of irrigation on $M . \times$ giganteus biomass production increased with the nitrogen level, whereas irrigation did not affect biomass production without nitrogen fertilization. With $100 \mathrm{~kg} \mathrm{~N} / \mathrm{ha}$, irrigation increased the biomass production by $3.7 \mathrm{t} \mathrm{DM} / \mathrm{ha}$, and with $200 \mathrm{~kg} \mathrm{~N} / \mathrm{ha}$, irrigation increased the biomass production by $9.8 \mathrm{t} \mathrm{DM} / \mathrm{ha}$ compared with the rainfed treatment over the first 4 years of cultivation.

These observations suggest that high $M . \times$ giganteus yields could be obtained with low nitrogen input levels because biomass production increases recorded with 0 and $200 \mathrm{~kg} \mathrm{~N} / \mathrm{ha}$ were moderate or insignificant. However, because the irrigation and nitrogen level influenced $M . \times$ giganteus biomass production in the interaction, 
it would be interesting to perform a more detailed investigation of the miscanthus capacity to produce high biomass under low nitrogen input and low irrigation levels with other Miscanthus species than M. $\times$ giganteus. Identifying clones that can produce a high biomass with the lowest environmental footprint (lowest water requirement and nitrogen fertilization levels) is necessary for improving miscanthus growth for bioenergy use.

- The influence of plant density

Different plant densities were used in miscanthus experiments ( 0.6 to 4 plants $/ \mathrm{m}^{2}$, see Tables 1 and 2), but only a few studies reported the effect of plant density on miscanthus biomass production. Danalatos et al. [80] observed that a 1- and 2-plants $/ \mathrm{m}^{2}$ density improved miscanthus biomass production compared with 0.67 plants $/ \mathrm{m}^{2}$ in central Greece. Based on this result, we suggest that the higher plant density increased biomass production. Based on this observation, two hypotheses can be formulated for the evolution of miscanthus biomass production over several years: (i) at higher plant density, biomass production will plateau more rapidly, and (ii) a higher plant density will yield higher biomass production levels during the plateau phase. More investigation is necessary to confirm these hypotheses and select an optimal plant density to maximize aboveground miscanthus biomass production. In addition, this choice should also depend on the cost of the miscanthus rhizomes because the expense of establishing the rhizome remains high.

Producing plantlets through vitro culture or producing seed-propagated varieties may be good alternatives for combining high plant densities, high biomass production, and lower establishment costs. Nevertheless, the environmental footprint, such as non-invasiveness, must also be preserved. For example, sterility must be obtained for seed-propagated varieties.

\section{The Influence of Species and Ploidy Level}

First, the Miscanthus species differed in biomass production and biomass components. With the average values 12 and $18 \mathrm{tDM} /$ ha for the winter harvest during the second and third years, respectively, $M . \times$ giganteus seemed the best biomass producer compared with the M. sacchariflorus and M. sinensis species (Fig. 4a). The M. $\times$ giganteus species also seemed better than the $M$. sacchariflorus and M. sinensis species. Moreover, the $M$. sinensis species seemed smaller than the $M . \times$ giganteus and M. sacchariflorus species (Fig. 4b). During the third year, the $M$. $\times$ giganteus species reached $231 \mathrm{~cm}$ on average, whereas the $M$. sacchariflorus and $M$. sinensis species reached 185 and $132 \mathrm{~cm}$, respectively (Fig. 4b). For stem number per plant, the $M$. sinensis and $M . \times$ giganteus species appeared to produce more stems than the $M$. sacchariflorus species. For example, the M. sinensis and M. $\times$ giganteus species produced 49 and 58 stems per plant on average, respectively, during the third year compared with the $M$. sacchariflorus species, which produced 26 stems (Fig. 4c). Finally, for stem diameter, the M. sacchariflorus and $M . \times$ giganteus species showed the highest values compared with the $M$. sinensis species for the second and third years of cultivation (Fig. 4d). For example, during the third year, the $M$. sacchariflorus and $M . \times$ giganteus species showed the mean stem diameters 7.2 and $5.6 \mathrm{~mm}$ on average, respectively, compared with $M$. sacchariflorus species, which exhibited the stem diameter $4.4 \mathrm{~mm}$ (Fig. 4d).

The range of variation within species was higher for $M$. sinensis than both the $M . \times$ giganteus and M. sacchariflorus species, particularly for biomass production and stem number per plant (Fig. 4a, c). For example, during the third year, the range of variation for aboveground biomass production and stem number per plant in the $M$. sinensis species reached 324 and $276 \%$ on average, respectively (Fig. 4a, c). In contrast, the range of variation for canopy height and stem diameter appeared similar among the three Miscanthus species (Fig. 4b, d).

For each trait, the genotype contribution to the phenotypic variability was high. This genotypic variability was more visible in the second and third years than the first year (Fig. 4). Moreover, this genotypic variability was generally more visible for the $M$. sinensis species than the $M$. $\times$ giganteus and M. sacchariflorus species (Fig. 4). This trend confirmed that the genotypic diversity among miscanthus is relatively high, particularly among the M. sinensis species [28].

Second, certain Miscanthus clones exhibited high biomass production and biomass component values and, thus, appeared suitable for biomass production in contrast to other clones that exhibited low values.

Interestingly, certain $M$. sinensis clones produced more biomass than certain M. $\times$ giganteus clones. Based on the studies shown in Fig. 4a, the maximum biomass production $31.9 \mathrm{t} \mathrm{DM} /$ ha was recorded for a hybrid composed of two M. sinensis clones (EMI no. 7) in Portugal with irrigation compared with a $30.6 \mathrm{tDM} / \mathrm{ha}$ maximum for a $M . \times$ giganteus clone (Greef et Deu.) in Italy with irrigation, as well as $100 \mathrm{~kg} \mathrm{~N} / \mathrm{ha}$ from a winter harvest during the third year of cultivation. Although a higher aboveground biomass production of $49 \mathrm{t} \mathrm{DM} /$ ha was recorded for a $M . \times$ giganteus clone in France under irrigated conditions [83], based on these observations, we suggest that specific $M$. sinensis clones can produce more biomass than certain $M . \times$ giganteus clones under specific climate conditions and locations. This suggestion was confirmed by the results from Clifton-Brown et al. [44]. In addition, certain studies have reported the superiority of certain Miscanthus hybrids for biomass production compared with non-hybrids. For example, Clifton-Brown et al. [44] 
observed that $M$. sinensis hybrids (EMI nos. 6-10) produced $31 \%$ more biomass on average than non-hybrid $M$. sinensis clones (EMI nos. 11-15) during a winter harvest in the third year of cultivation.

Considering the biomass components, two M. sinensis clones tested in Northern France [41] showed a high stem number per plant: $M$. sinensis Herman Müssel reached 85 stems during the second year of cultivation, and $M$. sinensis Silberspinne reached 176 stems during the third year of cultivation (Fig. 4c). One M. $\times$ giganteus clone (Flo) that was also tested in Northern France [41] showed a high stem diameter, reaching $9.8 \mathrm{~mm}$ in the third year (Fig. $4 \mathrm{~d}$ ).

Finally, ploidy level influenced the biomass production and its components. Glowaka et al. [84] observed significant but contrasting effects on biomass production and its components from increasing the ploidy level, depending on the genotype. Interestingly, the authors generated polyploid forms for certain genotypes, which showed more dry matter, higher plants, or a greater stem diameter compared with the corresponding controls. The results from Zub et al. [41] suggest that the miscanthus tetraploid or triploid forms were more productive than the diploid forms, and although the miscanthus forms studied were from distinct backgrounds, they reinforced the results from Glowaka et al. [84]. These results show that a greater ploidy level can improve biomass production.

Despite these encouraging results, this investigation must be considered in its context for several reasons. First, the species compared from various environments did not have the same genetic background. Second, the number of clones used differed between the three Miscanthus species studied: fewer clones were observed for the $M . \times$ giganteus and $M$. sacchariflorus species than the $M$. sinensis species; this could partially explain the lower variability in the $M . \times$ giganteus and M. sacchariflorus species. Finally, the effect of ploidy level on biomass production and its components seemed to differ based on the genotype.

The Phenotypic Variability for the Traits Related to Biomass Composition

\section{The Influence of Crop Age}

Allison et al. [45] studied the effect of year of cultivation on cellulose, hemicellulose, and lignin contents in miscanthus. Based on their experiments, the authors suggested that miscanthus biomass composition remained relatively consistent over the successive second, third, and fourth years.

Clifton-Brown and Lewandowski [43] compared several miscanthus clones for ash content in aboveground biomass during the first 3 years of cultivation. They observed that this content decreased from 8.9 to $2.3 \%$ DM on average between the first and third years during the winter harvest (Fig. 5). Moreover, with a $79 \%$ range of variation during the first year, the ash content appeared more variable during the first year compared with the second and third years (Fig. 5).

\section{The Influence of Geographical Area}

By studying the biomass compositions of 15 Miscanthus genotypes in five European locations during the third year of cultivation, Lewandowski et al. [37] showed that the ash content in the aboveground biomass varied based on the experiment location. Hodgson et al. [33] also highlighted a significant effect from location on cellulose and hemicellulose contents in the aboveground biomass. In contrast, these authors showed that this effect was not significant for lignin content in the aboveground biomass.

The influence of location on biomass composition could be partly explained by climatic conditions. The rainfall differences between locations could cause mineral leaching. Wind force differences between locations could affect the composition due to leaf loss [38].

These observations demonstrated that miscanthus biomass composition differed based on location. However, in contrast to biomass production, for which clear trends between Northern Europe countries and Central/Southern Europe countries have been highlighted [37], no clear trends identified an area that is most suitable for miscanthus biomass composition.

\section{The Influence of Crop Management Practices}

- The influence of harvest date

The cellulose and lignin contents in the aboveground biomass increased from 40.6 to $46.4 \% \mathrm{DM}$ and 8.0 to $9.4 \% \mathrm{DM}$ on average between the autumn and winter harvests, respectively (Fig. 6a, c). In contrast, the hemicellulose content tended decreased between the two harvest dates with the averages 29.4 and $28.8 \%$ DM during the autumn and winter harvests, respectively (Fig. 6b). These cellulose, hemicellulose, and lignin content differences between the autumn and winter harvests could be due to leaf loss between the two harvest dates [69].

Delaying the harvest time also significantly decreased the ash content $[37,43,70]$ as well as cutting the biomass and leaving it in the field [71]. For example, the ash content decreased from 3.9 to $2.5 \% \mathrm{DM}$ on average between the autumn and winter harvests during the third year of cultivation (Fig. 6d).

In addition, the genotype contribution to phenotypic variability was high for cellulose, hemicellulose, lignin, and ash contents in the aboveground biomass (Fig. 6).

Finally, with variations ranging from 25 to $213 \%$ during the third year of cultivation, the cellulose, hemicellulose, lignin, and ash contents were highly variable traits (Fig. 6). Interestingly, the highest ranges of variation for 
ash content (145 and $213 \%)$ showed that this trait was more variable than cellulose, hemicellulose, and lignin contents regardless of the harvest date (Fig. 6).

- The influence of nitrogen fertilization

Hodgson et al. [32] showed that the nitrogen input negatively impacted the $M . \times$ giganteus biomass quality; when nitrogen input increased, the cellulose, hemicellulose, and lignin contents in the aboveground biomass decreased, while ash increased. The authors concluded that low nitrogen fertilization yielded better quality biomass for thermochemical processes. These observations were encouraging as environmentally and economically beneficial and as contributor to cropping system sustainability.

\section{The Influence of Species}

Differences among Miscanthus species were highlighted for cellulose, hemicellulose, lignin, and ash contents during the winter harvest of the third year of cultivation (Fig. 7). With the average values of 47.3 and $49.4 \% \mathrm{DM}$, respectively, the $M$. × giganteus and $M$. sacchariflorus species appeared to contain more cellulose than the M. sinensis species (Fig. 7a). Moreover, with the average values of 10.0 and $10.6 \% \mathrm{DM}$, respectively, the $M$. $\times$ giganteus and $M$. sacchariflorus species also seemed to exhibited higher lignin content than the M. sinensis species (Fig. 7c). In contrast, with the average value $30.2 \% \mathrm{DM}$, the $M$. sinensis species exhibited higher hemicellulose content than the $M . \times$ giganteus and M. sacchariflorus species (Fig. 7b). Finally, with the average value of $1.6 \% \mathrm{DM}$, the M. sacchariflorus species exhibited lower ash content in the aboveground biomass than the $M . \times$ giganteus and $M$. sinensis species (Fig. 7d).

In addition, range of variation seemed variable based on the Miscanthus species and its traits. The range of variation for the cellulose and hemicellulose contents seemed to be the same as for the M. $\times$ giganteus, M. sinensis, and M. sacchariflorus species. In contrast, the range of variation for the lignin and ash contents appeared significantly lower for the M. sacchariflorus species than for the $M . \times$ giganteus and M. sinensis species. Among the traits studied, the ash content seemed the most variable trait with a range of variation of up to $178 \%$ compared to the cellulose, hemicellulose, and lignin contents in the aboveground biomass (Fig. 7).

Finally, for each trait, the portion of phenotypic variability due to the genotype was high, except for the M. sacchariflorus species, for which a single clone has been studied (Fig. 7).

The biomass composition observations among the Miscanthus species can only be considered trends because only few clones were used in the studies reported in Fig. 7, wherein only a single $M$. sacchariflorus clone, six $M$. × giganteus clones, and eight $M$. sinensis clones were used.
Interestingly, certain Miscanthus clones showed high cellulose and hemicellulose contents, and low lignin and ash contents. Certain M. sinensis clones presented lower minimal ash content than $M$. sacchariflorus clones (Fig. 7d): Clifton-Brown and Lewandowski [43] and Lewandowski et al. [37] identified two M. sinensis clones (Sin-11 and Sin-15) with the lowest ash content. Moreover, one $M . \times$ giganteus clone (EMI08) studied in England by Hodgson et al. [33] showed lower minimum lignin content than M. sinensis clones (Fig. 7c).

These observations suggest that certain Miscanthus species or clones are useful for breeding programs considering biomass composition. In addition, two papers reinforced the suggestions based on these data: the study by Allison et al. [45] which did not indicate individual values, and the study by Hodgson et al. [46] which concerned older crops that were 9 years old.

Key Points and Conclusions on Phenotypic Variability for Miscanthus Biomass Production and Biomass Composition

The present review shows that the traits of interest related to biomass production and biomass composition were generally highly variable for miscanthus. Among these traits, aboveground biomass production and stem number per plant appeared more variable than canopy height and stem diameter with values up to $300 \%$ during the third year, the range of variation for the aboveground biomass production and stem number per plant were approximately 2 -fold greater than the range of variation for the canopy height and stem diameter. Interestingly, for the biomass composition, the ash content in the aboveground biomass appeared to be the most variable trait; with values that could reach over $200 \%$, the range of variation for ash content reached levels 5-fold greater than the range of variation for cellulose, hemicellulose, and lignin contents. Moreover, the genotype contribution to the phenotypic variability was high for each trait studied.

Therefore, the high phenotypic variability for the traits studied and high genotype contribution to the variability were important for enhancing miscanthus breeding for bioenergy.

In addition, most of the factors of variation investigated in this review influenced the traits related to biomass production and biomass composition and, therefore, must be considered in breeding programs.

Miscanthus biomass production and canopy height appeared to mainly be influenced by crop age. With the maximum mean up to $13.0 \mathrm{t} \mathrm{DM} / \mathrm{ha}$ and $176 \mathrm{~cm}$ during the third year of cultivation, the biomass production and canopy height may be approximately 2.2- and 2.7-fold greater for a 3-yearold crop than a 1-year-old crop, respectively. 
Similarly, the stem number per plant seemed mainly affected by the crop age and species: (i) With the maximum mean at 53 stems per plant in a 3-year-old crop, the stem number per plant increased 2.5-fold from the first to third year, and (ii) in comparison, with the maximum mean 58 stems in the $M$. sinensis species, the stem number per plant was 2.2-fold greater in the M. sinensis species than in the M. sacchariflorus species, which showed the lowest mean in the third year of cultivation.

The stem diameter appeared to mainly be influenced by species; with the maximum mean $7.2 \mathrm{~mm}$ for the M. sacchariflorus species, the stem diameter was 1.6fold greater than for the $M$. sinensis species, which showed the lowest mean during the third year of cultivation.

For biomass composition, the cellulose, hemicellulose, and lignin contents in the aboveground biomass appeared to be, at a same level, most affected by the harvest date and species, while it was not affected by crop age.

With a $46.4 \% \mathrm{DM}$ average during the winter harvest, the cellulose content was 1.1-fold greater during the winter harvest than the autumn harvest during the third year of cultivation. Similarly, with a $9.4 \% \mathrm{DM}$ average during the winter harvest, the lignin content was 1.2 -fold higher during the winter harvest than the autumn harvest during the third year of cultivation. In contrast, with the mean $28.8 \%$ DM during the winter harvest, the hemicellulose content was similar during the winter and autumn harvests in the third year of cultivation. In comparison, with means up to 49.4 and $10.6 \% \mathrm{DM}$ in M. sacchariflorus species, the cellulose and lignin contents were, respectively, 1.1- and 1.2-fold greater in this species than in the M. sinensis species, which exhibited the lowest average values. With the maximum mean $30.2 \%$ DM in the $M$. sinensis species, the hemicellulose content was 1.2-fold greater in this species than in the M. sacchariflorus species, which exhibited the lowest average value.

The ash content in the aboveground miscanthus biomass appeared mainly affected by the crop age. With the average $2.3 \% \mathrm{DM}$ in a 3-year-old crop, the ash content can decrease by 3.9 from the first to the third year.

Therefore, developing miscanthus as sustainable feedstock for bioenergy required tackling such factors that influence traits related to biomass production and composition.

With bioenergy use as the breeding objective, the phenotypic variability, the genotype contribution to this variability, and the factors of variation investigated in the present review yielded guidelines (i) to select the traits for consideration in breeding programs, (ii) to propose the miscanthus species or clones that appear interesting as progenitors for breeding, and (iii) to select the optimal crop age, crop management practices, or geographical areas.

\section{Implications for Miscanthus Breeding Considering the Industrial Requirements for Bioenergy Use}

Few studies have investigated the ability to transform lignocellulosic crops through the different bioenergy conversion processes on an industrial scale. However, the researchers and industrial companies involved in recent bioenergy projects have begun to generate more precise requirements for optimizing lignocellulosic crop biomass production and composition.

First, for biomass production, the industry supports the notion that biomass production per hectare must be maximized under various climates with a lower environmental footprint for both biomass conversion processes: biochemical and thermochemical processes (Table 3(A)).

Second, although the lignocellulosic crop biomass composition requirements have not been fully defined by the industry, data are available from several private partners or publications. These data concern cellulose, hemicellulose, lignin, and ash contents in aboveground biomass, which are considered the main traits that impact biomass conversion efficiency.

Lignin and ash content appear to be the main traits that affect thermochemical process efficiency. High lignin content is preferable for this process because high lignin content aids in improving calorific value [32, 33, 85] (Table 3(A)). In contrast, low ash content is preferred, especially for combustion, as it implies a more efficient combustion processes, higher heating values, lower $\mathrm{NO}_{\mathrm{x}}$ emissions and, thus, lower combustion costs [37, 38] (Table 3(A)).

Cell wall composition and, more particularly, cellulose, hemicelluloses, and lignins appear to be the main traits that affect biochemical process efficiency. The cell wall composition and its digestibility must be optimized to ensure high sugar extraction efficiency in biochemical processes $[31,86]$. Among cellulose, hemicelluloses, and lignins, lignins seem the main restrictive factors because they apparently limit microbial accessibility of fermentescible sugars stored in the cell wall during fermentation [34-36]. Cellulose and hemicellulose contents also affect the efficiency of such processes during hydrolysis or fermentation [31, 87]. Based on these observations and the initial results from recent projects, the industry expects high cellulose and hemicellulose contents but low lignin and ash contents to enhance the efficiency of biochemical processes [Colonna, Dumas, personal communication, 88] (Table 3(A)). However, a favorable balance between lignin, cellulose, and hemicellulose for this process has not been fully defined because (i) data for the influence of biomass composition on this process' efficiency have not been published, and (ii) the methods used to assess biomass cell wall components differ, are not standardized, and yield variable results [31].

All these industrial requirements regarding biomass production and composition as well as the high genotypic 
variability described for these miscanthus traits herein aid in proposing guidelines for developing miscanthus breeding programs to produce bioenergy.

Firstly, the industry must maximize lignocellulosic crop biomass production for each bioenergy conversion process (Table 3(A)). Based on the current investigation, breeding programs must include developing varieties that (i) reach their maximum production potential per hectare in a specific environment and (ii) are adapted to a wide range of climates. Among the three Miscanthus species studied in this review, the $M . \times$ giganteus species and certain $M$. sinensis species clones appear particularly interesting because they produce a high quantity of biomass per hectare (Table 3(B)). Although the $M$. sacchariflorus species and $M$. sinensis species produce lower biomass per hectare on average than the $M . \times$ giganteus species (Table 3(B)), these species can offer progenitors for breeding programs because they are adapted to a wider range of climates than M. $\times$ giganteus. Moreover, breeding programs must consider nitrogen and water use efficiencies for a low environmental impact. In addition, traits such as canopy height, stem number per plant, or stem diameter must be considered in miscanthus breeding programs because these traits correlate with biomass production [40, 41].

Secondly, although the industrial requirements for lignocellulosic crop biomass composition have not been fully defined, these requirements appear to contrast based on the conversion processes (Table 3(A)). Therefore, currently, improving biomass composition is the most important challenge for bioenergy breeding programs to improve the efficiency and economic expense of conversion processes [31]. Based on the present review, we conclude that the species to consider may differ based on the conversion process. A given Miscanthus species may be suitable for one conversion process but not another. For thermochemical processes, such as combustion, pyrolysis, or gasification, the $M . \times$ giganteus and M. sacchariflorus species seemed better adapted than the $M$. sinensis species due to their high lignin content (Table 3(B)). For biochemical processes, such as hydrolysis, fermentation, or methanation, the $M . \times$ giganteus and M. sacchariflorus species were also interesting because they had high cellulose content. However, these species also had high lignin content, which can reduce efficiency for these processes (Table 3(B)); therefore, they were not entirely suitable. One M. $\times$ giganteus clone (EMI08) and the M. sinensis species showed lower lignin content and, therefore, may be particularly interesting for improving lignin content from biochemical processes in breeding programs (Table 3(B)). As low ash content is more suitable for all of these processes (Table (3A)), it may also be interesting to consider the M. sacchariflorus species for improving this trait because this species contained less ash than the $M . \times$ giganteus and M. sinensis species (Table 3(B)). The two M. sinensis clones 
(Sin-11 and Sin-15) also appeared interesting because they had the lowest ash content.

In addition to these guidelines, other factors that influence miscanthus biomass production and composition must be considered. The variability described in this reviews allow us to suggest that mature miscanthus crops are more suitable than younger crops for these processes due to (i) the maximum canopy height, stem number, and biomass production, as well as (ii) the lower ash content. Moreover, for thermochemical processes and, more particularly, combustion, delaying the miscanthus harvest date from autumn to winter yielded a better biomass composition, which leads to better combustion efficiency [38]. Hodgson et al. [33] also predicted that the winter harvest is more suitable for thermochemical processes because the calorific value of the winter-harvested biomass should increase. Finally, delaying the harvest date decreased the drying and transport expenses because the moisture content was lower for the winter harvest. Therefore, the winter miscanthus harvest appeared more economical than the autumn harvest for such conversion processes [89, 90]. Interestingly, the crop age and harvest date recommendations are consistent with recommendations from agronomical and environmental perspectives [91].

\section{Prospects}

The present review provides relevant information on genotypic and environmental variability for the biomass production and composition of the three Miscanthus species which gained most of the attention today. The broad genotypic variability in these traits shows that the potential for improving miscanthus as a bioenergy feedstock is great. However, miscanthus is a recent undomesticated crop; this review shows that little information on miscanthus biomass production and composition has been reported compared with major crops, and it must be genetically improved. Therefore, more information is necessary.

The relationships between the traits related to biomass production and composition that have not been studied for miscanthus until now must be investigated. It is important to improve the biomass composition while at least maintaining the biomass production. Moreover, little information about the heritability has been reported up to now. Heritability for these traits must be thoroughly investigated in the future. The present review showed extreme clones for many traits of interest, which can guide the breeder to create the relevant populations for assessing such estimates of heritability. In addition, miscanthus germplasm collections must be developed because the current collections do not cover the broad genetic diversity in the Miscanthus genus. Exploring miscanthus species other than the three Miscanthus species discussed herein may be promising for assessing new and interesting variables for miscanthus breeding. In addition, the breeding considerations for biomass composition should be accompanied by a complete definition of the industrial requirements for the different bioenergy conversion processes.

Finally, the results from the present investigation on miscanthus can be extrapolated to other monocotyledons or perennial crops that are close to miscanthus from a taxonomic perspective; sugarcane, sorghum, or maize are also promising feedstock candidates for bioenergy production. Enhancing other lignocellulosic crops is particularly interesting for the industry. The most sustainable scenario currently proposed includes developing crop areas close to local facilities. The most suitable feedstock for each facility will have to fulfill a continuous supply of the facility and will depend on the area's climatic and soil conditions. Therefore, this feedstock will be composed not only of a single crop but a set of several crops specifically adapted to the production area and harvested at different times throughout the year to continuously supply the facilities.

Acknowledgments The authors acknowledge the FUTUROL project, which supported this work. We particularly thank Catherine Bastien for her helpful comments on the manuscript and for asking the relevant question that initiated this manuscript. We also thank Isabelle Lejeune-Hénaut, Catherine Giauffret, Marion Zapater, Jean Carpentier, and the anonymous reviewers for their valuable recommendations.

Open Access This article is distributed under the terms of the Creative Commons Attribution License which permits any use, distribution, and reproduction in any medium, provided the original author(s) and the source are credited.

\section{References}

1. Greenpeace (2013) Scénario de transition énergétique, $27 \mathrm{p}$

2. Eurelectric (2011) Power choices pathways to carbon-neutral electricity in Europe by 2050, Full Report, Union of the Electricity Industry, $100 \mathrm{p}$

3. EREC (2010) RE-thinking 2050, a $100 \%$ renewable energy vision for the European Union, $76 \mathrm{p}$

4. ECF (2010) Roadmap 2050: a practical guide to a prosperous, lowcarbon Europe, Technical Analysis, $100 \mathrm{p}$

5. IEA/OECD (2006) Perspectives des Technologies de l'Energie, Scénarios et Stratégies à l'horizon 2050, Synthèse et Implications Stratégiques. International Energy Agency (IEA), $15 \mathrm{p}$

6. Cadoux S, Ferchaud F, Demay C, Boizard H, Machet J-M, Fourdinier E, Preudhomme M, Chabbert B, Gosse G, Mary B (2014) Implications of productivity and nutrient requirements on greenhouse gas balance of annual and perennial bioenergy crops. GCB Bioenergy 6:425-438

7. Karp A, Shield I (2008) Bioenergy from plants and the sustainable yield challenge. New Phytol 179:15-32

8. Sanderson MA, Adler PR (2008) Perennial forages as second generation bioenergy crops. Int J Mol Sci 9:768-788

9. Zegada-Lizarazu W, Parrish D, Berti M, Monti A (2013) Dedicated crops for advanced biofuels: consistent and diverging agronomic points of view between the USA and the EU-27. Biofuels Bioprod Biorefin 7:715-731

10. Rabelo SC, Carrere H, Filho RM, Costa AC (2011) Production of bioethanol, methane and heat from sugarcane bagasse in a biorefinery concept. Bioresour Technol 102:7887-7895 
11. Dillen SY, Djomo SN, Al Afas N, Vanbeveren S, Ceulemans R (2013) Biomass yield and energy balance of a short-rotation poplar coppice with multiple clones on degraded land during 16 years. Biomass Bioenergy 56:157-165

12. Nissim WG, Pitre FE, Teodorescu TI, Labrecque M (2013) Longterm biomass productivity of willow bioenergy plantations maintained in southern Quebec, Canada. Biomass Bioenergy 56:361-369

13. Vermerris W (2011) Survey of genomics approaches to improve bioenergy traits in maize, sorghum and sugarcane free access. $\mathrm{J}$ Integr Plant Biol 53:105-119

14. Souza A, Grandis A, Leite DC, Buckeridge M (2014) Sugarcane as a bioenergy source: history, performance, and perspectives for secondgeneration bioethanol. Bioenergy Res 7:24-35

15. Hastings A, Clifton-Brown J, Wattenbach M, Stampfl P, Mitchell CP, Smith P (2008) Potential of Miscanthus grasses to provide energy and hence reduce greenhouse gas emissions. Agron Sustain Dev 28:465-472

16. Heaton EA, Dohleman FG, Long SP (2008) Meeting US biofuel goals with less land: the potential of Miscanthus. Glob Chang Biol 14:2000-2014

17. Dohleman FG, Long SP (2009) More productive than maize in the Midwest: how does miscanthus do it? Plant Physiol 150:2104-2115

18. Wagoner P (1990) Perennial grain development - past efforts and potential for the future. Crit Rev Plant Sci 9:381-408

19. Arundale RA, Dohleman FG, Heaton EA, McGrath JM, Voigt TB, Long SP (2014) Yields of Miscanthus $\times$ giganteus and Panicum virgatum decline with stand age in the Midwestern USA. Glob Chang Biol Bioenergy 6:1-13

20. Dohleman FG, Heaton EA, Leakey ADB, Long SP (2009) Does greater leaf-level photosynthesis explain the larger solar energy conversion efficiency of Miscanthus relative to switchgrass? Plant Cell Environ 32:1525-1537

21. Cadoux S, Ferchaud F, Preudhomme M, Demay C, Fourdinier E, Strullu L, Mary B, Machet JM, Boizard H, Gosse G (2010) Production de biomasse et impacts environnementaux des cultures énergétiques, Colloque final du programme REGIX, 3-7 mai 2010, Lyon, France, pp 27-39

22. Clifton-Brown JC, Stampfl PF, Jones MB (2004) Miscanthus biomass production for energy in Europe and its potential contribution to decreasing fossil fuel carbon emissions. Glob Chang Biol 10:509-518

23. Lewandowski I, Schmidt U (2006) Nitrogen, energy and land use efficiencies of Miscanthus, reed canary grass and triticale as determined by the boundary line approach. Agric Ecosyst Environ 112: 335-346

24. Hodkinson TR, Chase MW, Takahashi C, Leitch IJ, Bennett MD, Renvoize SA (2002) The use of DNA sequencing (ITS and trnL-F), AFLP, and fluorescent in situ hybridization to study allopolyploid Miscanthus (Poaceae). Am J Bot 89:279-286

25. Zub HW, Arnoult S, Younous J, Lejeune-Hénaut I, BrancourtHulmel M (2012) The frost tolerance of Miscanthus at the juvenile stage: differences between clones are influenced by leaf-stage and acclimation. Eur J Agron 36:32-40

26. Cosentino SL, Patane C, Sanzone E, Copani V, Foti S (2007) Effects of soil water content and nitrogen supply on the productivity of Miscanthus $\times$ giganteus Greef et Deu. in a Mediterranean environment. Ind Crop Prod 25:75-88

27. de Cesare M, Hodkinson TR, Barth S (2010) Chloroplast DNA markers (cpSSRs, SNPs) for Miscanthus, Saccharum and related grasses (Panicoideae, Poaceae). Mol Breed 26:539-544

28. Greef JM, Deuter M, Jung C, Schondelmaier J (1997) Genetic diversity of European Miscanthus species revealed by AFLP fingerprinting. Genet Resour Crop Evol 44:185-195

29. Zub HW, Brancourt-Hulmel M (2010) Agronomic and physiological performances of different species of Miscanthus, a major energy crop. A review. Agron Sustain Dev 30:201-214

30. Greef JM, Deuter M (1993) Syntaxonomy of Miscanthus $\times$ giganteus Greef-et-Deu. Angew Bot 67:87-90
31. Jakob K, Zhou FS, Paterson A (2009) Genetic improvement of C4 grasses as cellulosic biofuel feedstocks. In Vitro Cell Dev Biol Plant 45:291-305

32. Hodgson EM, Fahmi R, Yates N, Barraclough T, Shield I, Allison G, Bridgwater AV, Donnison IS (2010) Miscanthus as a feedstock for fast-pyrolysis: does agronomic treatment affect quality? Bioresour Technol 101:6185-6191

33. Hodgson EM, Lister SJ, Bridgwater AV, Clifton-Brown J, Donnison IS (2010) Genotypic and environmentally derived variation in the cell wall composition of Miscanthus in relation to its use as a biomass feedstock. Biomass Bioenergy 34:652-660

34. Klimiuk E, Pokoj T, Budzynski W, Dubis B (2010) Theoretical and observed biogas production from plant biomass of different fibre contents. Bioresour Technol 101:9527-9535

35. Monlau F, Barakat A, Trably E, Dumas C, Steyer JP, Carrere H (2013) Lignocellulosic materials into biohydrogen and biomethane: impact of structural features and pretreatment. Crit Rev Environ Sci Technol 43:260-322

36. Boudet AM, Kajita S, Grima-Pettenati J, Goffner D (2003) Lignins and lignocellulosics: a better control of synthesis for new and improved uses. Trends Plant Sci 8:576-581

37. Lewandowski I, Clifton-Brown JC, Andersson B, Basch G, Christian DG, Jorgensen U, Jones MB, Riche AB, Schwarz KU, Tayebi K, Teixeira F (2003) Environment and harvest time affects the combustion qualities of Miscanthus genotypes. Agron J 95:1274-1280

38. Lewandowski I, Kicherer A (1997) Combustion quality of biomass: practical relevance and experiments to modify the biomass quality of Miscanthus $\times$ giganteus. Eur J Agron 6:163-177

39. Gauder M, Graeff-Hönninger S, Lewandowski I, Claupein W (2012) Long-term yield and performance of 15 different Miscanthus genotypes in southwest Germany. Ann Appl Biol 160:126-136

40. Jezowski S (2008) Yield traits of six clones of Miscanthus in the first 3 years following planting in Poland. Ind Crop Prod 27:65-68

41. Zub HW, Arnoult S, Brancourt-Hulmel M (2011) Key traits for biomass production identified in different Miscanthus species at two harvest dates. Biomass Bioenergy 35:637-651

42. Clifton-Brown JC, Chiang YC, Hodkinson TR (2008) Miscanthus: genetic resources and breeding potential to enhance bioenergy production. In: Vermerris W (ed) Genetic improvement of bioenergy crops. Springer, USA, pp 273-294

43. Clifton-Brown JC, Lewandowski I (2002) Screening Miscanthus genotypes in field trials to optimise biomass yield and quality in Southern Germany. Eur J Agron 16:97-110

44. Clifton-Brown JC, Lewandowski I, Andersson B, Basch G, Christian DG, Kjeldsen JB, Jorgensen U, Mortensen JV, Riche AB, Schwarz KU, Tayebi K, Teixeira F (2001) Performance of 15 Miscanthus genotypes at five sites in Europe. Agron J 93:1013-1019

45. Allison GG, Morris C, Clifton-Brown J, Lister SJ, Donnison IS (2011) Genotypic variation in cell wall composition in a diverse set of 244 accessions of Miscanthus. Biomass Bioenergy 35:4740-4747

46. Hodgson EM, Nowakowski DJ, Shield I, Riche A, Bridgwater AV, Clifton-Brown JC, Donnisona IS (2011) Variation in Miscanthus chemical composition and implications for conversion by pyrolysis and thermo-chemical bio-refining for fuels and chemicals. Bioresour Technol 102:3411-3418

47. Kalembasa D, Jezowski S, Pude R, Malinowska E (2005) The content of carbon, hydrogen and nitrogen in different development stage of some clones of Miscanthus. Pol J Soil Sci 38:169-177

48. Lewandowski I, Heinz A (2003) Delayed harvest of miscanthus influences on biomass quantity and quality and environmental impacts of energy production. Eur J Agron 19:45-63

49. Le Ngoc Huyen T, Rémond C, Dheilly RM, Chabbert B (2010) Effect of harvesting date on the composition and saccharification of Miscanthus $\times$ giganteus. Bioresour Technol 101:8224-8231

50. Mos M, Banks SW, Nowakowski DJ, Robson PRH, Bridgwater AV, Donnison IS (2013) Impact of Miscanthus $\times$ giganteus senescence 
times on fast pyrolysis bio-oil quality. Bioresour Technol 129:335342

51. Amougou N, Bertrand I, Machet JM, Recous S (2011) Quality and decomposition in soil of rhizome, root and senescent leaf from Miscanthus $\times$ giganteus, as affected by harvest date and $\mathrm{N}$ fertilization. Plant Soil 338:83-97

52. Kim SJ, Kim MY, Jeong SJ, Jang MS, Chung IM (2012) Analysis of the biomass content of various Miscanthus genotypes for biofuel production in Korea. Ind Crop Prod 38:46-49

53. Van Soest PJ, Wine RH (1967) Use of detergents in the analysis of fibrous feeds. IV. Determination of plant cell-wall constituents. J Assoc Off Anal Chem 50:50-55

54. Hulle S, Waes C, Vliegher A, Baert J, Muylle H (2012) Comparison of dry matter yield of lignocellulosic perennial energy crops in a longterm Belgian field experiment, Grassland - a European resource? Proceedings of the 24th General Meeting of the European Grassland Federation, Lublin, Poland, 3-7 June 2012

55. Qin J, Yang Y, Jiang J, Yi Z, Xiao L, Ai X, Chen Z (2012) Comparison of lignocellulose composition in four major species of Miscanthus. Afr J Biotechnol 11:12529-12537

56. Van Hulle S, Roldan-Ruiz I, Van Bockstaele E, Muylle H (2010) Comparison of different low-input lignocellulosic crops as feedstock for bio-ethanol production. In: C Huyghe (ed) Proceedings of the conference of the Eucarpia Fodder and Amenity Species Section: sustainable use of genetic diversity in forage and turf breeding, 2010

57. Christian DG, Riche AB, Yates NE (2008) Growth, yield and mineral content of Miscanthus $\times$ giganteus grown as a biofuel for 14 successive harvests. Ind Crop Prod 28:320-327

58. Angelini LG, Ceccarini L, Di Nassa NNO, Bonari E (2009) Comparison of Arundo donax L. and Miscanthus $\times$ giganteus in a long-term field experiment in Central Italy: analysis of productive characteristics and energy balance. Biomass Bioenergy 33:635-643

59. Mantineo M, D'Agosta GM, Copani V, Patane C, Cosentino SL (2009) Biomass yield and energy balance of three perennial crops for energy use in the semi-arid Mediterranean environment. Field Crop Res 114:204-213

60. Jezowski S, Glowacka K, Kaczmarek Z (2011) Variation on biomass yield and morphological traits of energy grasses from the genus Miscanthus during the first years of crop establishment. Biomass Bioenergy 35:814-821

61. Strullu L, Cadoux S, Preudhomme M, Jeuffroy MH, Beaudoin N (2011) Biomass production and nitrogen accumulation and remobilisation by Miscanthus $\times$ giganteus as influenced by nitrogen stocks in belowground organs. Field Crop Res 121:381-391

62. Behnke GD, David MB, Voigt TB (2012) Greenhouse gas emissions, nitrate leaching, and biomass yields from production of Miscanthus $\times$ giganteus in Illinois, USA. Bioenergy Res 5:801-813

63. Dohleman FG, Heaton EA, Arundale RA, Long SP (2012) Seasonal dynamics of above- and below-ground biomass and nitrogen partitioning in Miscanthus $\times$ giganteus and Panicum virgatum across three growing seasons. GCB Bioenergy 4:534-544

64. Arundale R, Dohleman F, Voigt T, Long S (2014) Nitrogen fertilization does significantly increase yields of stands of Miscanthus $\times$ giganteus and Panicum virgatum in multiyear trials in Illinois. Bioenergy Res. doi:10.1007/s12155-013-9385-5:1-9

65. Haines SA, Gehl RJ, Havlin JL, Ranney TG (2014) Nitrogen and phosphorus fertilizer effects on establishment of giant Miscanthus. Bioenergy Res. doi:10.1007/s12155-014-9499-4:1-11

66. Larsen SU, Jorgensen U, Kjeldsen JB, Laerke PE (2014) Long-term Miscanthus yields influenced by location, genotype, row distance, fertilization and harvest season. Bioenergy Res 7:620-635

67. Palmer IE, Gehl RJ, Ranney TG, Touchell D, George N (2014) Biomass yield, nitrogen response, and nutrient uptake of perennial bioenergy grasses in North Carolina. Biomass Bioenergy 63:218-228
68. Dagnelie P (1969) Théorie et méthodes statistiques. Presses agronomiques, Gembloux

69. Hayes DJM (2013) Mass and compositional changes, relevant to biorefining, in Miscanthus $\times$ giganteus plants over the harvest window. Bioresour Technol 142:591-602

70. Baxter XC, Darvell LI, Jones JM, Barraclough T, Yates NE, Shield I (2012) Study of Miscanthus $\times$ giganteus ash composition - variation with agronomy and assessment method. Fuel 95:50-62

71. Meehan PG, Finnan JM, Mc Donnell KP (2013) The effect of harvest date and harvest method on the combustion characteristics of Miscanthus $\times$ giganteus. Glob Chang Biol Bioenergy 5:487-496

72. Lewandowski I, Scurlock JMO, Lindvall E, Christou M (2003) The development and current status of perennial rhizomatous grasses as energy crops in the US and Europe. Biomass Bioenergy 25:335-361

73. Clifton-Brown J, Long SP, Jorgensen U (2001) Miscanthus productivity. In: Jones M, Walsh M (eds) Miscanthus for energy and fibre. James and james, London, pp 46-67

74. Miguez FE, Villamil MB, Long SP, Bollero GA (2008) Meta-analysis of the effects of management factors on Miscanthus $\times$ giganteus growth and biomass production. Agric For Meteorol 148:1280-1292

75. Heaton E, Voigt T, Long SP (2004) A quantitative review comparing the yields of two candidate $\mathrm{C}-4$ perennial biomass crops in relation to nitrogen, temperature and water. Biomass Bioenergy 27:21-30

76. Christian DG, Haase E (2001) Agronomy of miscanthus. In: Jones MB, Walsh M (eds) Miscanthus for energy and fibre. James and james, London, pp 21-45

77. Beale CV, Bint DA, Long SP (1996) Leaf photosynthesis in the C-4grass Miscanthus $\times$ giganteus, growing in the cool temperate climate of southern England. J Exp Bot 47:267-273

78. Himken M, Lammel J, Neukirchen D, CzypionkaKrause U, Olfs HW (1997) Cultivation of Miscanthus under west European conditions: seasonal changes in dry matter production, nutrient uptake and remobilization. Plant Soil 189:117-126

79. Cadoux S, Riche AB, Yates NE, Machet J-M (2012) Nutrient requirements of Miscanthus $\times$ giganteus: conclusions from a review of published studies. Biomass Bioenergy 38:14-22

80. Danalatos NG, Archontoulis SV, Mitsios I (2007) Potential growth and biomass productivity of Miscanthus $\times$ giganteus as affected by plant density and $\mathrm{N}$-fertilization in central Greece. Biomass Bioenergy 31:145-152

81. Acaroglu M, Aksoy AS (2005) The cultivation and energy balance of Miscanthus $\times$ giganteus production in Turkey. Biomass Bioenergy 29:42-48

82. Ercoli L, Mariotti M, Masoni A, Bonari E (1999) Effect of irrigation and nitrogen fertilization on biomass yield and efficiency of energy use in crop production of Miscanthus. Field Crop Res 63:3-11

83. Tayot X, Chartier M, Varlet-Grancher C, Lemaire G (1995) Potential above-ground dry matter production of miscanthus in north-central France compared to sweet sorghum. In: Chartier P, Beenackers A, Grassi G (eds) Biomass for energy, environment, agriculture and industry. Elsevier, Oxford, pp 556-564

84. Glowacka K, Jezowski S, Kaczmarek Z (2010) In vitro induction of polyploidy by colchicine treatment of shoots and preliminary characterisation of induced polyploids in two Miscanthus species. Ind Crop Prod 32:88-96

85. Fahmi R, Bridgwater A, Donnison I, Yates N, Jones JM (2008) The effect of lignin and inorganic species in biomass on pyrolysis oil yields, quality and stability. Fuel 87:1230-1240

86. Zhao X, Zhang L, Liu D (2012) Biomass recalcitrance. Part I: the chemical compositions and physical structures affecting the enzymatic hydrolysis of lignocellulose. Biofuels Bioprod Bioref Biofpr 6: 465-482

87. Slavov G, Allison G, Bosch M (2013) Advances in the genetic dissection of plant cell walls: tools and resources available in Miscanthus. Front Plant Sci 4:217. doi:10.3389/fpls.2013.00217 
88. Monlau F, Sambusiti C, Barakat A, Guo XM, Latrille E, Trably E, Steyer J-P, Carrere H (2012) Predictive models of biohydrogen and biomethane production based on the compositional and structural features of lignocellulosic materials. Environ Sci Technol 46: $12217-12225$

89. Huisman W, Venturi P, Molenaar J (1997) Costs of supply chains of Miscanthus giganteus. Ind Crop Prod 6:353-366
90. Van den Heuvel EMJT (1995) Pretreatment technologies for energy crops. Final Report of Novem Project 355300/0302. BTG, Enschede, the Netherlands, $69 \mathrm{p}$

91. Brancourt-Hulmel M, Demay C, Rosiau E, Ferchaud F, Bethencourt L, Arnoult S, Dauchy C, Beaudoin N, Boizard H (2014) Miscanthus genetics and agronomy for bioenergy feedstock. In: Karlen DL (ed) Cellulosic energy cropping systems. Wiley, UK, pp 43-74 